Hydrology and Earth System Sciences, 8(5), 973-992 (2004) C EGU

\title{
Dependence between sea surge, river flow and precipitation in south and west Britain*
}

\author{
Cecilia Svensson and David A. Jones \\ Centre for Ecology and Hydrology, Wallingford, OX10 8BB, UK \\ Email for corresponding author: csve@ceh.ac.uk
}

\begin{abstract}
Estuaries around Great Britain may be at heightened risk of flooding because of the simultaneous occurrence of extreme sea surge and river flow, both of which may be caused by mid-latitude cyclones. A measure especially suited for extremes was employed to estimate dependence between river flow and sea surge. To assist in the interpretation of why flow-surge dependence occurs in some areas and not in others, the dependence between precipitation and surge and between precipitation and river flow was also studied. Case studies of the meteorological situations leading to high surges and/or river flows were also carried out. The present study concerns catchments draining to the south and west coasts of Great Britain. Statistically significant dependence between river flow and daily maximum sea surge may be found at catchments spread along most of this coastline. However, higher dependence is generally found in catchments in hilly areas with a southerly to westerly aspect. Here, precipitation in south-westerly airflow, which is generally the quadrant of prevailing winds, will be enhanced orographically as the first higher ground is encountered. The sloping catchments may respond quickly to the abundant rainfall and the flow peak may arrive in the estuary on the same day as a large sea surge is produced by the winds and low atmospheric pressure associated with the cyclone. There are three regions where flow-surge dependence is strong: the western part of the English south coast, southern Wales and around the Solway Firth. To reduce the influence of tide-surge interaction on the dependence analysis, the dependence between river flow and daily maximum surge occurring at high tide was estimated. The general pattern of areas with higher dependence is similar to that using the daily maximum surge. The dependence between river flow and daily maximum sea surge is often strongest when surge and flow occur on the same day. The west coast from Wales and northwards has slightly stronger flow-surge dependence in summer than in winter, whereas dependence is stronger in winter than in summer for the southern part of the study area.
\end{abstract}

Keywords: Britain, dependence, sea surge, river flow, precipitation, mid-latitude cyclone, seasonality, time lag

\section{Introduction}

Mid-latitude cyclones may cause both sea surges and (via precipitation) river flow. If the surge and flow peaks arrive simultaneously in estuaries, there will be an increased risk of flooding. Understanding of the risks posed by combinations of extreme events is crucial for the successful management of these hazards.

A sea surge is the difference between the total observed sea level and the predicted astronomical tide. It is also

*During the course of the research related to the present paper, the authors have published some additional work (Svensson and Jones, 2004). This summarises the results of applying similar methodology to study winter-season dependence of surge and river flow around the whole of Britain. referred to as the 'meteorological residual', or the 'weather effect', as it is influenced by winds and atmospheric pressure (Pugh, 1987). When a depression moves into a sea area, the atmospheric pressure acting normal to the sea surface falls and the sea level rises. A reduction in pressure of $1 \mathrm{mb}$ corresponds to a rise in the water level of about $1 \mathrm{~cm}$ and vice versa. The effect of the wind, which is the more important in shallow waters, results in the water being dragged in a similar direction to the wind, but deflected to the right (in the northern hemisphere) because of the Coriolis effect (Hunt, 1972).

On the west coast, surges tend to be locally generated by the low atmospheric pressure and southerly to westerly winds associated with a depression approaching Britain from the west or south-west (Lennon, 1963; Heaps, 1967). The 
depressions are often of a secondary nature, moving anticlockwise around the parent depression to its north (Lennon, 1963). Positive surge events on the west coast often last between about 9 and 15 hours (Heaps, 1967).

The magnitudes of both sea surges and river flows vary with the seasons. Mid-latitude cyclonic activity affecting the British Isles is more vigorous during autumn and winter than during the rest of the year (e.g. Wallén, 1970), resulting in both higher sea surges (Pugh, 1987) and more abundant frontal precipitation (Manley, 1970). Orographic enhancement, which is more prominent in winter, increases the precipitation on windward slopes (e.g. Harrison, 1997). Because of the predominantly westerly winds, this is particularly pronounced in the western parts of the country (Mayes and Wheeler, 1997). In general, the month with the highest frequency of floods occurs in late autumn and winter in large areas of the north and west of Britain, similar to the seasonality of intense cyclones and associated precipitation. However, catchments to the south and east show more of a late winter and early spring seasonality. This is because the soil moisture content in these catchments generally returns to near field capacity later in the year. The result is a later onset and a shorter flood season (Bayliss and Jones, 1993).

The majority of cyclones travel from west to east, in latitudes north of Scotland, or from south-west to northeast past the Hebrides (Manley, 1970). When studying midseason months, this or similar patterns emerge for most of the year (October, January and April). However, during the summer (July), the main storm track is typically further to the south, crossing Scotland from west to east (Whittaker and Horn, 1984).

To the authors' knowledge no other authors have published studies of the dependence between sea surge and river flow on the British south and west coasts. However, Samuels and Burt (2002) investigated the dependence between river flow on the Taff at Pontypridd and total sea levels at Cardiff in south Wales. They extracted the 20 highest peak river flows and paired them with the corresponding high water levels nearest in time. They concluded that there was no correlation between the series, and that the corresponding water levels were not unusually high (which would have suggested that there might be dependence). Weston (1979) quantified the magnitudes of freshwater flow and tide that combine to certain observed water levels of the tidal Dee in north Wales, but did not include a frequency estimate or study of the dependence between the variables.

Methods to establish whether or not there is dependence between the variables are described in, for example, van der Made (1969) and Loganathan et al. (1987). The former investigated the dependence between river flow in the river Rhine in the Netherlands and water levels in the North Sea.
The dependence problem was approached by comparing the frequency of river flows occurring simultaneously with extreme storm surges, with the frequency of river flows occurring regardless of the size of surge. The frequencies were found not to be significantly different from each other and, thus, there was no dependence.

Loganathan et al. (1987) concluded that there was dependence between flow in the Rappahannock River and water levels in the Chesapeake Bay on the east coast of the United States. In this case, iso-lines of empirical exceedance probability were plotted in a diagram of water level versus streamflow and showed that high flows tended to occur simultaneously with high water levels.

Mantz and Wakeling (1979) investigated dependence by comparing the predicted return period for a joint river flow and sea surge flood event assuming independence, with the actual return period of flooding calculated from records. They found little difference between the predicted and actual return periods for three rivers in Norfolk, England, and concluded that surge and flow occurred independently.

Svensson and Jones (2002) investigated the dependence between river flow and sea surges on the British east coast, where sea level data are more complete and the behaviour of sea surges is altogether better understood than on the south and west coasts. The study found dependence mainly in the northern part of the east coast. The present study extends the earlier study to identify areas that may be at heightened risk of flooding on the remaining coasts of Great Britain. Considering the importance of orographic enhancement of precipitation to dependence on the east coast, it was hypothesised that the predominantly windward catchments on the south and west coasts would be similarly at risk. The same methodology was used for the new study, that is, a dependence measure especially suited for extremal dependence was used.

To assist in the interpretation of why flow-surge dependence occurs in some areas and not in others, the dependence between precipitation and surge and between precipitation and river flow was also studied. Seasonal and lagged analyses were carried out to explore the details of the dependence further. Where dependence between sea surge and river flow was found, the meteorological situations causing high flows and/or surges have been identified.

A fuller account of the results of this study can be found in the interim project report (Svensson and Jones, 2003). Svensson and Jones (2004) summarises the results of applying similar methodology to study winter-season dependence of sea surge and river flow around the whole of Britain in relation to the North Atlantic Oscillation Index. 


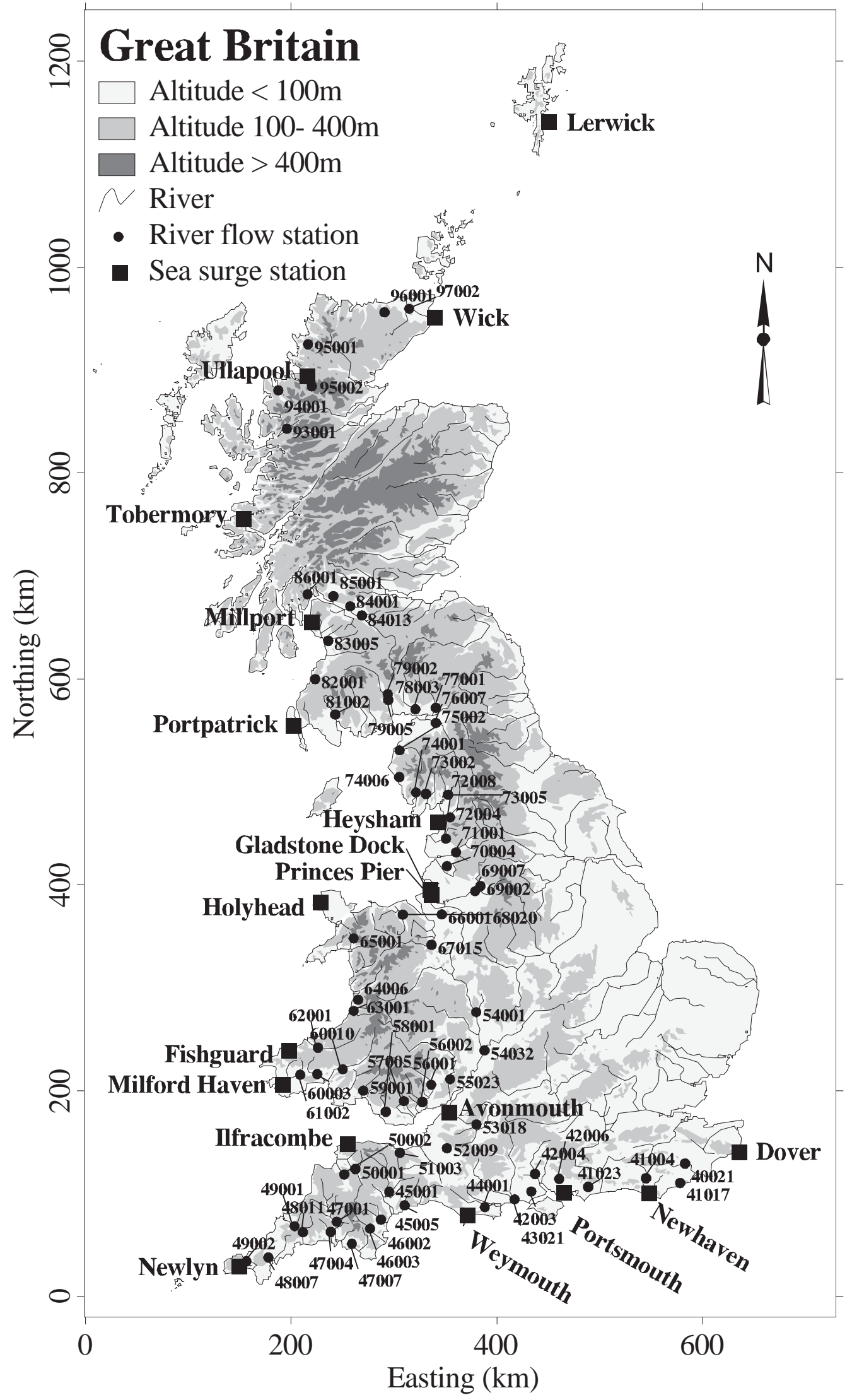

Fig. 1. Location of sea level stations and river flow stations 
Table 1. General information about the 19 sea level stations. The easting and northing coordinates are in the Great Britain national grid coordinate system. Missing data refer to the extracted daily maximum surge series.

\begin{tabular}{|c|c|c|c|c|}
\hline Station & $\begin{array}{l}\text { Easting } \\
(\mathrm{km})\end{array}$ & $\begin{array}{l}\text { Northing }(\mathrm{km}) \\
(\mathrm{km})\end{array}$ & $\begin{array}{l}\text { Mean daily maxi- } \\
\text { mum surge ( } \mathrm{mm})\end{array}$ & $\begin{array}{l}\text { Missing data } \\
\text { (\%) }\end{array}$ \\
\hline Wick & 336.7 & 950.8 & 66 & 19.1 \\
\hline Lerwick & 447.8 & 1141.4 & 67 & 14.3 \\
\hline Ullapool & 212.9 & 893.9 & 99 & 32.1 \\
\hline Tobermory & 150.8 & 755.3 & 107 & 74.4 \\
\hline Millport & 217.7 & 654.5 & 150 & 51.3 \\
\hline Portpatrick & 199.8 & 554.2 & 102 & 18.9 \\
\hline Heysham & 340.3 & 460.1 & 198 & 16.9 \\
\hline Liverpool Princes Pier & 333.6 & 390.6 & 316 & 48.0 \\
\hline Liverpool Gladstone Dock & 332.5 & 395.3 & 205 & 78.3 \\
\hline Holyhead & 225.5 & 382.9 & 101 & 35.5 \\
\hline Fishguard & 195.1 & 238.8 & 108 & 11.2 \\
\hline Milford Haven & 189.2 & 205.3 & 130 & 18.2 \\
\hline Avonmouth & 350.6 & 179.0 & 381 & 61.8 \\
\hline Ilfracombe & 252.6 & 147.9 & 153 & 51.3 \\
\hline Newlyn & 146.8 & 28.6 & 82 & 2.9 \\
\hline Waymouth & 368.4 & 78.9 & 104 & 73.4 \\
\hline Portsmouth & 462.7 & 100.5 & 132 & 75.0 \\
\hline Newhaven & 545.1 & 100.1 & 154 & 66.5 \\
\hline Dover & 632.7 & 140.3 & 160 & 16.5 \\
\hline
\end{tabular}

\section{Data}

\section{SEA SURGE}

Hourly sea surge and total sea level data covering the period 1963-2001 for 19 stations on the British south and west coasts were used (Fig. 1, Table 1). The surge residuals were calculated as the difference between the observed total sea level and the predicted astronomical tide. Surge has a stronger link with meteorology than does total sea level, the latter being largely influenced by the variability of the astronomical tide. Using surge data is, therefore, better for identifying the causal processes of flooding in estuaries.

Daily series of maximum surge, and of maximum surge occurring at high tide, were derived for the water day, 9.009.00 GMT. The daily maximum surge was thought to have the strongest connection with precipitation and river flow because of the relatively short duration of very high surges. However, because of tide-surge interaction in shallow waters, daily maximum surge occurring at high tide was also extracted from the hourly data.

There are two records for Liverpool. The means of daily maximum surge for Liverpool Princes Pier (1963-1986) and Liverpool Gladstone Dock (1993-2001) are rather different (316 and $205 \mathrm{~mm}$ ). This decrease in the mean between the two time periods is inconsistent with the changes at three of four surrounding stations (Portpatrick, Holyhead and Fishguard show increases, whereas Heysham shows a decrease) for the same time periods. Therefore, the two Liverpool sites were treated as two separate records rather than being aggregated into one long record.

The paper deals with the dependence between a pair of variables, and does not discuss the frequency of occurrence of the marginal distributions. More information on extreme surges can be found in Department of Energy (1977 and 1984). These offshore design guidelines cover the whole of the British Isles.

\section{RIVER FLOW}

Daily mean river flows, generally for 9.00-9.00 GMT, for 72 stations in catchments draining to the south and west coasts of Great Britain, were extracted for the period 19632001 (Fig. 1, Table 2) from the National River Flow Archive at $\mathrm{CEH}$ Wallingford. The stations were chosen to be as far downstream as possible without being tidally influenced and to have as few missing data as possible. For the Severn, two nested catchments were used because the downstream station 54032 (Severn at Saxons Lode), commonly used for general analysis, is tidally influenced at high tides.

Daily mean river flows were used rather than sub-daily 
Table 2. General information about the 72 river flow stations. The easting and northing coordinates are in the Great Britain national grid coordinate system. Missing data: 0 denotes a complete record, and 0.0 denotes that less than $0.05 \%$ is missing.

\begin{tabular}{|c|c|c|c|c|c|c|c|c|}
\hline Station & River & Location & $\begin{array}{l}\text { Easting } \\
(\mathrm{km})\end{array}$ & $\begin{array}{l}\text { Northing } \\
(\mathrm{km})\end{array}$ & $\begin{array}{l}\text { Altitude } \\
\text { (m) }\end{array}$ & $\begin{array}{l}\text { Area } \\
\left(\mathrm{km}^{2}\right)\end{array}$ & $\begin{array}{l}\text { Meanriver } \\
\text { flow }\left(\mathrm{m}^{3} / \mathrm{s}\right)\end{array}$ & $\begin{array}{l}\text { Missing } \\
\text { data(\%) }\end{array}$ \\
\hline 40021 & Hexden Channel & Hopemill Br Sandhurst & 581.3 & 129.0 & 5.2 & 32 & 0.3 & 48.2 \\
\hline 41004 & Ouse & Barcombe Mills & 543.3 & 114.8 & 5.2 & 396 & 3.6 & 19.7 \\
\hline 41017 & Combe Haven & Crowhurst & 576.5 & 110.2 & 1.9 & 31 & 0.3 & 18.0 \\
\hline 41023 & Lavant & Graylingwell & 487.1 & 106.4 & 20.7 & 87 & 0.3 & 21.1 \\
\hline 42003 & Lymington & Brockenhurst & 431.8 & 101.9 & 6.1 & 99 & 1.0 & 0.8 \\
\hline 42004 & Test & Broadlands & 435.4 & 118.9 & 10.1 & 1040 & 10.8 & 0.2 \\
\hline 42006 & Meon & Mislingford & 458.9 & 114.1 & 29.3 & 73 & 1.0 & 0.0 \\
\hline 43021 & Avon & Knapp Mill & 415.6 & 94.3 & 0.9 & 1706 & 19.9 & 33.1 \\
\hline 44001 & Frome & East Stoke Total & 386.6 & 86.7 & $\sim 9$ & 414 & 6.4 & 12.0 \\
\hline 45001 & Exe & Thorverton & 293.6 & 101.6 & 25.9 & 601 & 16.0 & 0 \\
\hline 45005 & Otter & Dotton & 308.7 & 88.5 & 14.5 & 203 & 3.2 & 0 \\
\hline 46002 & Teign & Preston & 285.6 & 74.6 & 3.8 & 381 & 9.2 & 2.6 \\
\hline 46003 & Dart & Austins Bridge & 275.1 & 65.9 & 22.4 & 248 & 11.0 & 2.6 \\
\hline 47001 & Tamar & Gunnislake & 242.6 & 72.5 & 8.2 & 917 & 22.4 & 0 \\
\hline 47004 & Lynher & Pillaton Mill & 236.9 & 62.6 & 8.5 & 136 & 4.6 & 2.0 \\
\hline 47007 & Yealm & Puslinch & 257.4 & 51.1 & 5.5 & 55 & 1.7 & 2.8 \\
\hline 48007 & Kennal & Ponsanooth & 176.2 & 37.7 & 13.6 & 27 & 0.5 & 14.7 \\
\hline 48011 & Fowey & Restormel & 209.8 & 62.4 & 9.2 & 169 & 4.9 & 0.0 \\
\hline 49001 & Camel & Denby & 201.7 & 68.2 & 4.6 & 209 & 6.1 & 4.3 \\
\hline 49002 & Hayle & St Erth & 154.9 & 34.1 & 7.0 & 48 & 1.0 & 13.2 \\
\hline 50001 & Taw & Umberleigh & 260.8 & 123.7 & 14.1 & 826 & 18.5 & 0 \\
\hline 50002 & Torridge & Torrington & 250.0 & 118.5 & 13.9 & 663 & 16.0 & 0.0 \\
\hline 51003 & Washford & Beggearn Huish & 304.0 & 139.5 & 67.1 & 36 & 0.8 & 18.2 \\
\hline 52009 & Sheppey & Fenny Castle & 349.8 & 143.9 & 5.8 & 60 & 1.1 & 3.8 \\
\hline 53018 & Avon & Bathford & 378.5 & 167.0 & 18.0 & 1552 & 18.0 & 17.7 \\
\hline 54001 & Severn & Bewdley & 378.2 & 276.2 & 17.0 & 4325 & 60.6 & 0 \\
\hline 54032 & Severn & Saxons Lode & 386.3 & 239.0 & 7.5 & 6850 & 87.2 & 19.9 \\
\hline 55023 & Wye & Redbrook & 352.8 & 211.0 & 9.2 & 4010 & 76.0 & 0 \\
\hline 56001 & Usk & Chain Bridge & 334.5 & 205.6 & 22.6 & 912 & 27.9 & 0 \\
\hline 56002 & Ebbw & Rhiwderyn & 325.9 & 188.9 & 30.6 & 217 & 7.6 & 7.4 \\
\hline 57005 & Taff & Pontypridd & 307.9 & 189.7 & 45.1 & 455 & 19.7 & 20.5 \\
\hline 58001 & Ogmore & Bridgend & 290.4 & 179.4 & 13.8 & 158 & 6.7 & 2.2 \\
\hline 59001 & Tawe & Ynystanglws & 268.5 & 199.8 & 9.3 & 228 & 12.1 & 1.1 \\
\hline 60003 & Taf & Clog-y-Fran & 223.8 & 216.0 & 7.0 & 217 & 7.5 & 7.3 \\
\hline 60010 & Tywi & Nantgaredig & 248.5 & 220.6 & 7.8 & 1090 & 39.2 & 0.1 \\
\hline 61002 & Eastern Cleddau & Canaston Bridge & 207.2 & 215.3 & 5.0 & 183 & 6.0 & 0.2 \\
\hline 62001 & Teifi & Glan Teifi & 224.4 & 241.6 & 5.2 & 894 & 28.7 & 0 \\
\hline 63001 & Ystwyth & Pont Llolwyn & 259.1 & 277.4 & 12.0 & 170 & 6.0 & 2.1 \\
\hline 64006 & Leri & Dolybont & 263.5 & 288.2 & 14.6 & 47 & 1.3 & 0 \\
\hline 65001 & Glaslyn & Beddgelert & 259.2 & 347.8 & 32.9 & 69 & 5.8 & 0.4 \\
\hline 66001 & Clwyd & Pont-y-Cambwll & 306.9 & 370.9 & 15.3 & 404 & 6.3 & 0 \\
\hline 67015 & Dee & Manley Hall & 334.8 & 341.5 & 25.4 & 1019 & 30.9 & 0 \\
\hline 68020 & Gowy & Bridge Trafford & 344.8 & 371.1 & 4.1 & 156 & 1.1 & 42.7 \\
\hline 69002 & Irwell & Adelphi Weir & 382.4 & 398.7 & 24.1 & 559 & 17.5 & 3.3 \\
\hline 69007 & Mersey & Ashton Weir & 377.2 & 393.6 & 14.9 & 660 & 12.4 & 34.4 \\
\hline 70004 & Yarrow & Croston Mill & 349.8 & 418.0 & 6.9 & 74 & 1.9 & 35.6 \\
\hline 71001 & Ribble & Samlesbury & 358.7 & 431.4 & 6.0 & 1145 & 32.9 & 1.3 \\
\hline 72004 & Lune & Caton & 352.9 & 465.3 & 10.7 & 983 & 35.3 & 5.1 \\
\hline 72008 & Wyre & Garstang & 348.8 & 444.7 & 10.9 & 114 & 3.3 & 14.9 \\
\hline
\end{tabular}


Table 2 Contd.

\begin{tabular}{|c|c|c|c|c|c|c|c|c|}
\hline Station & River & Location & $\begin{array}{l}\text { Easting } \\
(\mathrm{km})\end{array}$ & $\begin{array}{l}\text { Northing } \\
(\mathrm{km})\end{array}$ & $\begin{array}{l}\text { Altitude } \\
\text { (m) }\end{array}$ & $\begin{array}{l}\text { Area } \\
\left(\mathrm{km}^{2}\right)\end{array}$ & $\begin{array}{l}\text { Meanriver } \\
\text { flow }\left(\mathrm{m}^{3} / \mathrm{s}\right)\end{array}$ & $\begin{array}{l}\text { Missing } \\
\text { data(\%) }\end{array}$ \\
\hline 73002 & Crake & Low Nibthwaite & 329.4 & 488.2 & 38.6 & 73 & 4.0 & 2.0 \\
\hline 73005 & Kent & Sedgwick & 350.9 & 487.4 & 18.9 & 209 & 8.9 & 15.0 \\
\hline 74001 & Duddon & Duddon Hall & 319.6 & 489.6 & 14.8 & 86 & 4.8 & 17.9 \\
\hline 74006 & Calder & Calder Hall & 303.5 & 504.5 & 26.4 & 45 & 1.8 & 9.3 \\
\hline 75002 & Derwent & Camerton & 303.8 & 530.5 & 16.7 & 663 & 25.8 & 0 \\
\hline 76007 & Eden & Sheepmount & 339.0 & 557.1 & 7.0 & 2287 & 51.9 & 12.2 \\
\hline 77001 & Esk & Netherby & 339.0 & 571.8 & 14.3 & 842 & 26.1 & 7.5 \\
\hline 78003 & Annan & Brydekirk & 319.1 & 570.4 & 10.0 & 925 & 29.5 & 12.2 \\
\hline 79002 & Nith & Friars Carse & 292.3 & 585.1 & 19.8 & 799 & 27.5 & 0 \\
\hline 79005 & Cluden Water & Fiddlers Ford & 292.8 & 579.5 & 22.9 & 238 & 7.9 & 1.9 \\
\hline 81002 & Cree & Newton Stewart & 241.2 & 565.3 & 4.8 & 368 & 15.7 & 1.9 \\
\hline 82001 & Girvan & Robstone & 221.7 & 599.7 & 9.1 & 246 & 6.6 & 2.0 \\
\hline 83005 & Irvine & Shewalton & 234.5 & 636.9 & 4.8 & 381 & 9.6 & 23.3 \\
\hline 84001 & Kelvin & Killermont & 255.8 & 670.5 & 27.0 & 335 & 8.6 & 0.1 \\
\hline 84013 & Clyde & Daldowie & 267.2 & 661.6 & 7.5 & 1903 & 48.8 & 2.0 \\
\hline 85001 & Leven & Linnbrane & 239.4 & 680.3 & 5.3 & 784 & 43.5 & 1.6 \\
\hline 86001 & Little Eachaig & Dalinlongart & 214.3 & 682.1 & 10.1 & 31 & 1.8 & 15.0 \\
\hline 93001 & Carron & New Kelso & 194.2 & 842.9 & 5.6 & 138 & 10.9 & 41.0 \\
\hline 94001 & Ewe & Poolewe & 185.9 & 880.3 & 4.6 & 441 & 29.7 & 20.0 \\
\hline 95001 & Inver & Little Assynt & 214.7 & 925.0 & 60.3 & 138 & 8.5 & 37.4 \\
\hline 95002 & Broom & Inverbroom & 218.4 & 884.2 & 4.6 & 141 & 7.3 & 56.5 \\
\hline 96001 & Halladale & Halladale & 289.1 & 956.1 & 23.2 & 205 & 5.1 & 33.3 \\
\hline 97002 & Thurso & Halkirk & 313.1 & 959.5 & 30.2 & 413 & 8.8 & 23.1 \\
\hline
\end{tabular}

flows as the latter were not available in digitised form for many relevant stations. Daily mean flows are indicative of the magnitude of the peak flow during the day, especially for more slowly responding catchments. However, it may not necessarily be the case that instantaneous peak flows would be more appropriate to use than mean flows, as water levels are influenced by the possibly rather slow change in storage in the estuary.

Information about statistical distributions of UK river flows is given by Robson and Reed (1999).

\section{PRECIPITATION}

Daily precipitation accumulations from 9.00 to 9.00 GMT were obtained from the UK Met Office. Precipitation data were extracted for the period 1963-2001 for 27 stations in catchments draining to the south and west coasts of Great Britain (locations are denoted with triangles in Fig. 6).

Eleven out of the 27 gauges have complete records. Station 741962 (Knockanrock) has the poorest record, with 27.4\% missing data. Information about statistical distributions of UK precipitation is given by Faulkner (1999).

\section{METEOROLOGICAL MAPS}

Meteorological information was gathered for a selection of flood and surge events. For events prior to 1981, this was obtained from the Daily Weather Report of the British Meteorological Office, and from 1981 onwards from the Daily Weather Summary compiled by the London Weather Centre. Prior to 1998 maps were drawn four times per day and showed the surface conditions over Britain and, at 12.00 GMT, for part of the northern hemisphere. From 1998 onwards only two maps per day are available.

\section{Methods}

\section{DEPENDENCE MEASURE $\chi$}

A dependence measure specially suited for estimating dependence as the variables reach their extremes was used. The measure, $\chi$, has been described in detail by Buishand (1984) and Coles et al. (2000). Buishand employed it to assess the inter-station dependence in precipitation data, whereas Coles et al. applied it to several different variables, among them precipitation and surge data. A brief outline of 
$\chi$, and of the methods for selection of threshold and for permutation to assess statistical significance are outlined below. A more comprehensive description is given by Svensson and Jones (2002).

When used for bivariate random variables $(X, Y)$ with identical marginal distributions, the measure $\chi$ provides an estimate of the probability of one variable being extreme provided that the other one is extreme:

$$
\chi=\lim _{z \rightarrow z^{*}} \operatorname{Pr}(Y>z \mid X>z)
$$

where $z^{*}$ is the upper limit of the observations of the common marginal distribution.

In this application the marginal distributions are not likely to be identical and are, therefore, transformed to become so. Further, the marginals are unknown and must be estimated using their empirical distributions. Thus, one approach to obtaining an estimate of identical marginal distributions is to rank each set of observations separately, and divide each rank by the total number of observations in each set. That is, the variables $X$ and $Y$ are transformed to variables $U$ and $V$ with Uniform $[0,1]$ margins, via $(U, V)=$ $\left\{F_{X}(X), F_{Y}(Y)\right\}$. The data sets transformed in this way contain complete information about the joint distribution but no longer have information on the marginal distributions.

The dependence measure $\chi(u)$ for a given threshold $u$ is defined as

$$
\chi(u)=2-\frac{\ln \operatorname{Pr}(U \leq u, V \leq u)}{\ln \operatorname{Pr}(U \leq u)} \text { for } 0 \leq u \leq 1 .
$$

The choice of the particular form in Eqn. (2) derives from the following argument (Buishand, 1984). If the random variables $U$ and $V$ are strictly independent, then

$$
\begin{aligned}
\operatorname{Pr}(U & \leq u, V \leq u)=\operatorname{Pr}(U \leq u) \operatorname{Pr}(V \leq u), \\
& =\{\operatorname{Pr}(U \leq u)\}^{2},
\end{aligned}
$$

while, if they are strictly dependent,

$$
\operatorname{Pr}(U \leq u, V \leq u)=\{\operatorname{Pr}(U \leq u)\} .
$$

The use of the same threshold, $u$, here for both variables $U$ and $V$ allows the simple form of the above expression. In terms of the original variables $X$ and $Y$, the threshold $u$ converts to thresholds for the two variables such that they have the same probability of being exceeded when each variable is treated separately. To represent intermediate degrees of dependence, a relation of the form

$$
\operatorname{Pr}(U \leq u, V \leq u)=\{\operatorname{Pr}(U \leq u)\}^{2-\chi(u)},
$$

can be written down. Equation (2) follows on solving this equation for $\chi(u)$. The quantity defined by Eqn. (2) is related to $\chi$ of Eqn. (1) by

$$
\chi=\lim _{u \rightarrow 1} \chi(u)=\lim _{u \rightarrow 1} \operatorname{Pr}(V>u \mid U>u) .
$$

This is justified by Coles et al. (2000) using the relation

$$
\begin{aligned}
\operatorname{Pr}(V>u \mid & >u)=\frac{\operatorname{Pr}(U>u, V>u)}{\operatorname{Pr}(U>u)} \\
& =\frac{1-2 \operatorname{Pr}(U \leq u)+\operatorname{Pr}(U \leq u, V \leq u)}{1-\operatorname{Pr}(U \leq u)} \\
& =2-\frac{1-\operatorname{Pr}(U \leq u, V \leq u)}{1-u},
\end{aligned}
$$

from which it follows that, for $u \rightarrow 1$,

$$
\begin{aligned}
\operatorname{Pr}(V & >u \mid U>u) \approx 2-\frac{\ln \operatorname{Pr}(U \leq u, V \leq u)}{\ln u} \\
& =2-\frac{\ln \operatorname{Pr}(U \leq u, V \leq u)}{\ln \operatorname{Pr}(U \leq u)}=\chi(u) .
\end{aligned}
$$

As the variables approach their extremes, $\chi(u)=1$ signifies total dependence and $\chi(u)=0$ signifies independence or negative dependence. Equation (3) allows a simple interpretation of the dependence measure $\chi(u)$. Suppose that one variable exceeds the threshold corresponding to a certain (small) exceedance probability. Then, if the dependence between the variables is estimated to be, say, $\chi(u)=0.1$, there is a $10 \%$ probability of the other variable exceeding the threshold corresponding to the same probability.

Equation (2) is the measure of dependence used in the present study. It can be evaluated at different quantile levels $u$. Suppose that a particular level $u$ has been selected, which corresponds to threshold levels $\left(x^{*}, y^{*}\right)$ for the observed series. Equation (2) is then applied by counting the number of observation-pairs, $(X, Y)$, so that

$$
\begin{aligned}
& \operatorname{Pr}(U \leq u, V \leq u)= \\
& \frac{\text { Number of }(X, Y) \text { such that } X \leq x^{*} \text { and } Y \leq y^{*}}{\text { Total number of }(X, Y)}
\end{aligned}
$$

and

$$
\begin{aligned}
& \ln \operatorname{Pr}(U \leq u)=. \\
& \quad \frac{1}{2} \ln \left(\frac{\text { Number of } X \leq x^{*}}{\text { Total number of } X} \cdot \frac{\text { Number of } Y \leq y^{*}}{\text { Total number of } Y}\right)
\end{aligned}
$$

The particular form of Eqn. (5) is used so that the pair of 
variables $\mathrm{X}$ and $\mathrm{Y}$ are treated symmetrically. From here onwards, $\chi$ will be used as a short-hand symbol for $\chi(u)$ for a given way of choosing $u$, rather than denoting the limit as expressed by Eqn. (1).

\section{SELECTION OF THRESHOLD LEVEL}

The dependence measure $\chi$ can be estimated for any threshold. Initial trials showed a fairly constant, slightly decreasing, value of $\chi$ for annual maximum non-exceedance probabilities between about 0.1 and 0.5 . For higher probabilities, $\chi$ tended to become 0 as no observation-pairs exceeded both thresholds (Appendix B of Svensson and Jones, 2000). The threshold was selected to be $a=0.1$. This corresponds to selecting a threshold for the data-values that will be exceeded by about 2.3 events per year. The annual maximum will exceed this threshold in 9 out of 10 years. The selection of threshold level has two requirements: to have enough data-points above the threshold to be able to estimate dependence reliably, and for the threshold to be high enough to regard the data-points as extreme.

\section{MISSING DATA}

Only observation-pairs where both observations in the pair were available were included in the counts in Eqns. (2), (4) and (5). A minimum of 1825 observation-pairs, equivalent to five complete years of simultaneous data, was set as a requirement for $\chi$ to be estimated reasonably reliably. For the seasonal analysis, this was reduced to 912 observationpairs.

\section{SIGNIFICANCE LEVEL}

The values of $\chi$ corresponding to the 5\% significance level were estimated using a permutation resampling method (e.g. Good, 1994). Numerous data-sets are generated and a test statistic, in this case $\chi$, is calculated for each of these new data-sets. This provides a sample of $\chi$ for independently occurring data. If the $\chi$ calculated for the original data-set is rather different from most of the $\chi$ calculated from the generated values, then this suggests that the two original records are not independent. Dependence occurring because both records show similar seasonal characteristics can be accounted for by generating data that show the same seasonal characteristics.

The permutation of the data was performed by randomly reshuffling intact blocks of one calendar year, to preserve the seasonality but to remove the dependence structure between the two series. In total, 199 permutations of the data were made for each station-pair and a new $\chi$ was calculated each time. The $199 \chi$ values were subsequently ranked in descending order and the 10th largest value was accepted as corresponding to the 5\% significance level, or the $95 \%$ point of the null distribution (the distribution of values that would occur if data-pairs were independent). If the $\chi$ calculated for the original series exceeds this value, then the data provides reasonably strong evidence that the dependence between the variables can be considered genuine.

\section{CONFIDENCE INTERVALS}

Confidence intervals give an indication of the range of values in which the 'true' dependence $\chi$ can be expected to lie. In the absence of infinitely long records, this true value is unknown. A bootstrapping method (e.g. Efron, 1979) was used to estimate the confidence intervals. Similar to the permutation method used for estimating significance, bootstrapping can be used where the underlying statistical population is unknown or where an analytical solution is impractical.

Bootstrapping is based on the generation of many new data-sets - resamples. In contrast to when significance levels were estimated and independence between the two series was sought, each observation-pair is here kept intact and treated as an item.

The original sample of observation-pairs is used as the distribution from which the resamples are chosen randomly with replacement, that is with each observation-pair being returned to the original sample after it has been chosen, so that it may be chosen again. Many data-sets are generated and a test statistic, in this case $\chi$, is calculated for each of these new data-sets. This provides a sample of $\chi$ that would occur for a range of situations, as $\chi$ is calculated from some resamples including many data-pairs consistent with dependence, and from some resamples including many datapairs consistent with independence. Seasonality is kept intact by sampling in blocks of one year, rather than using individual observation-pairs.

In this study, balanced resampling (e.g. Fisher, 1993) was used, which is a more efficient method. It ensures that each year occurs equally often overall among the total number of bootstrap samples. It is implemented by creating a vector of length $B N$ consisting of the $N$ years of record repeated $B$ times. This array is then randomly reshuffled and divided into slices of length $N$, to obtain $B$ bootstrap samples.

In total, $B=199$ bootstrap samples of the data were made for each station-pair and a new $\chi$ was calculated each time. The $199 \chi$ values were subsequently ranked in descending order and the 10th and 190th largest values were accepted as delimiting the $90 \%$ confidence interval. 


\section{DIVISION INTO SEASONS}

For the seasonal study, the data were divided into a summer season, April-September, and a winter season, OctoberMarch. In these cases, the threshold levels $\left(x^{*}, y^{*}\right)$ corresponding to $a=0.1$ change, since the same number of POTs (on average 2.3 POTs per season) are extracted using data from only part of the year, instead of from the whole year.

\section{Results and discussion}

A dependence measure $\chi$, suitable for estimating extremal dependence, was used to estimate the dependence between extreme sea surge, river flow and precipitation. River flow and sea surge both influence the water levels in estuaries, whereas precipitation is used to assist in the interpretation of why surge-flow dependence occurs in particular places and not in others.

Because the variables are used at a daily resolution, results are indicative only of where extreme river flow and sea surge may occur simultaneously. Modelling of how sea levels and river flow affect the water levels in the fluvial-tidal river reach needs to be done at a higher resolution to assess actual water levels. However, if there is no dependence at the resolution presented in this study (i.e. daily), it is unlikely that there will be dependence at a higher temporal resolution.

It should be noted that $\chi$ measures dependence in a general sense, including dependence arising from seasonality. However, the test of significance effectively tests whether there is more dependence than can be explained purely by seasonality.

\section{INTER-STATION DEPENDENCE}

The spatial extent of extreme events was investigated by estimating the dependence for all station-pair combinations for each variable separately. The inter-station dependence was plotted against distance for daily maximum sea surge, daily mean river flow and daily precipitation accumulations (Fig. 2). Values of $\chi$ that are significant at the 5\% level (exceed the $95 \%$ point of the null distribution) are shown as filled circles, whereas non-significant values are shown as empty circles. Although the measure $\chi$ is not appropriate for measuring negative dependence, a few flow station-pairs had an estimated $\chi$ less than the $5 \%$ point of the null distribution. This can be indicative of independence as well as negative dependence. These values are shown as stars on the plot.

Of the three variables, surge shows the strongest spatial dependence and precipitation the weakest. For flow and precipitation, the strength of dependence is reasonably
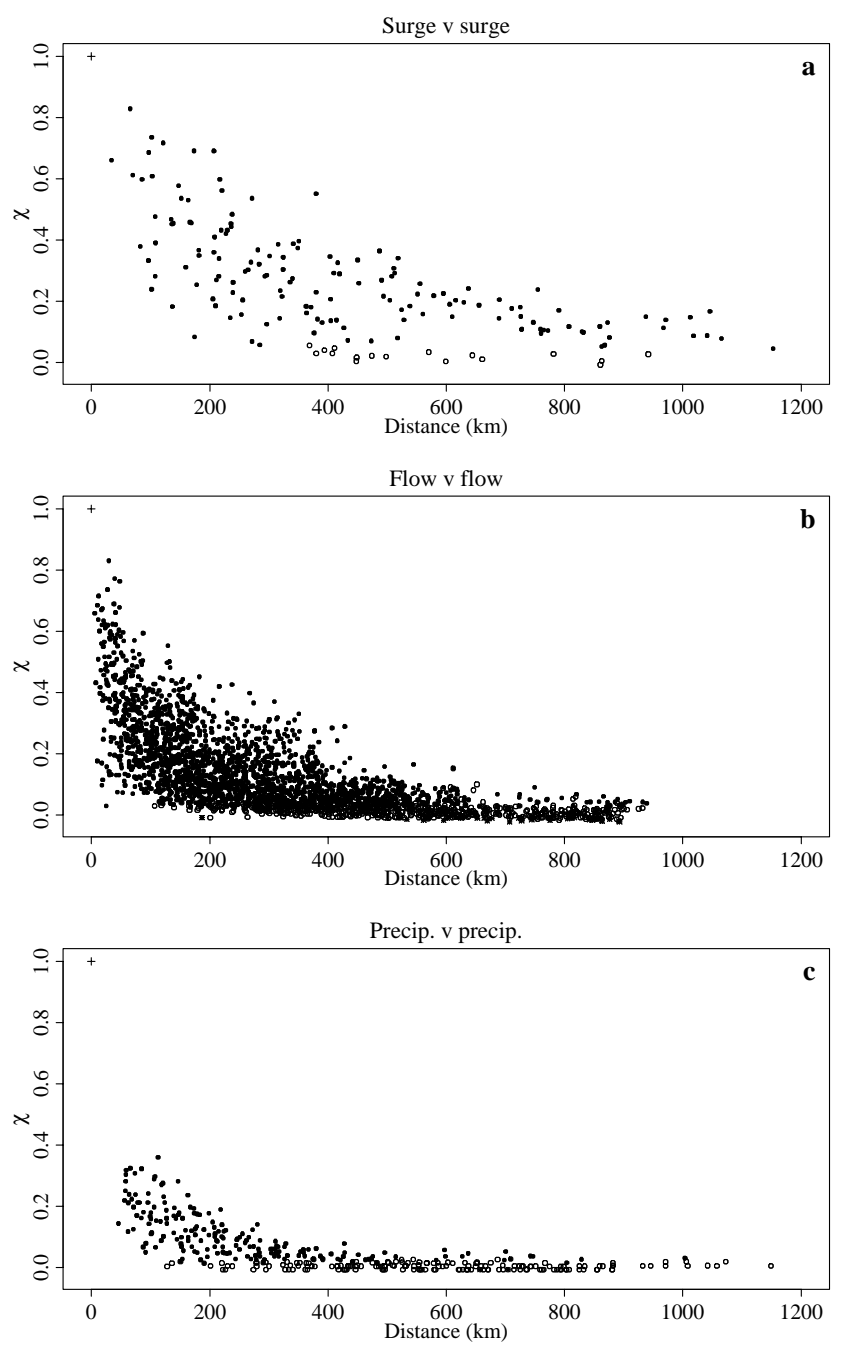

Fig. 2. Inter-station dependence versus distance in (a) daily maximum sea surge, (b) river flow, and (c) precipitation. Values of $\chi$ significant at the 5\% level are shown as filled circles and nonsignificant values as empty circles. Stars indicate independent or negatively dependent values. All possible combinations of stationpairs are used.

similar to that found in eastern Britain (see Svensson and Jones, 2002), with some dependence in river flow being stronger in the west than in the east. However, the scatter of the points for the surge (Fig. 2a) is much greater in the west than in the east (not shown, see Svensson and Jones (2002) for a related plot, of $\chi$ versus difference in northing), with the top envelope being of similar magnitude. On the east coast, surges are often generated north of Scotland, and travel down the east coast (Pugh, 1987), resulting in a well structured dependence behaviour of the surge. Dependence is much more variable on the west coast, presumably because of the complex coastline and the obstruction of the Irish landmass to wind-induced water movement from the west. 
The dependence in surge is stronger on the west coast than on the south coast, and dependence is weaker in the eastern part of the south coast than in the western. From west to east, similarly distanced station-pairs show decreasing dependence: $\chi=0.42$ for Newlyn and Weymouth, $\chi=0.25$ for Weymouth and Newhaven, and $\chi$ $=0.08$ for Portsmouth and Dover. This may be related to the incursion of North Sea surges into the English Channel from the east.

\section{FLOW-SURGE DEPENDENCE}

Dependence between daily mean river flow and daily maximum sea surge is shown in Fig. 3. Locations of river flow stations are denoted by circles and surge stations by squares. Where dependence is significant, or exceeds a particular threshold, lines connect station-pairs that neighbour each other. That is, one surge station on either side of the river estuary is paired with the river flow station, unless the surge station is located in, or very near, the estuary in which case only that surge station is used. Because of the very short surge records for Portsmouth and Weymouth, the river flow stations between these surge stations have also been paired with the long surge record at Newlyn. The two river flow gauges in the northernmost part of the country, 96001 and 97002, have been paired with surges at Ullapool, Lerwick and Wick. Note that Liverpool has two surge records, Princes Pier and Gladstone Dock. River flow stations between Heysham and Holyhead have, therefore, also been paired with (up to) three surge stations. One station-pair (Liverpool Princes Pier and 68020) has too few simultaneous observations for $\chi$ to have been estimated. However, the record for Liverpool Gladstone Dock sufficiently overlaps that of 68020 .

Dependence between river flow and sea surge can vary over short distances as each river responds differently depending on its catchment characteristics, such as area and geology. Small and impervious catchments generate faster runoff with a shorter time to peak flow than larger and more permeable catchments. The site-specific nature of the river flow characteristics means that a dense network of gauges is needed, and results may be difficult to generalise to a larger area. However, some regional patterns emerge.

Although dependence significant at the 5\% level may be found at catchments spread along most of the coastline, higher dependence $(\chi>0.1)$ is generally found in three regions: the western part of the English south coast, southern Wales, and around the Solway Firth. These are hilly areas with a southerly to westerly aspect. Here, precipitation in southwesterly airflow, which is generally the quadrant of prevailing winds (e.g. Barrow and Hulme, 1997), will be orographically enhanced as the first higher ground is encountered. The sloping catchments may respond quickly to the abundant rainfall, and the flow peak may arrive in the estuary on the same day as a large sea surge.

The generally low dependence on the eastern part of the
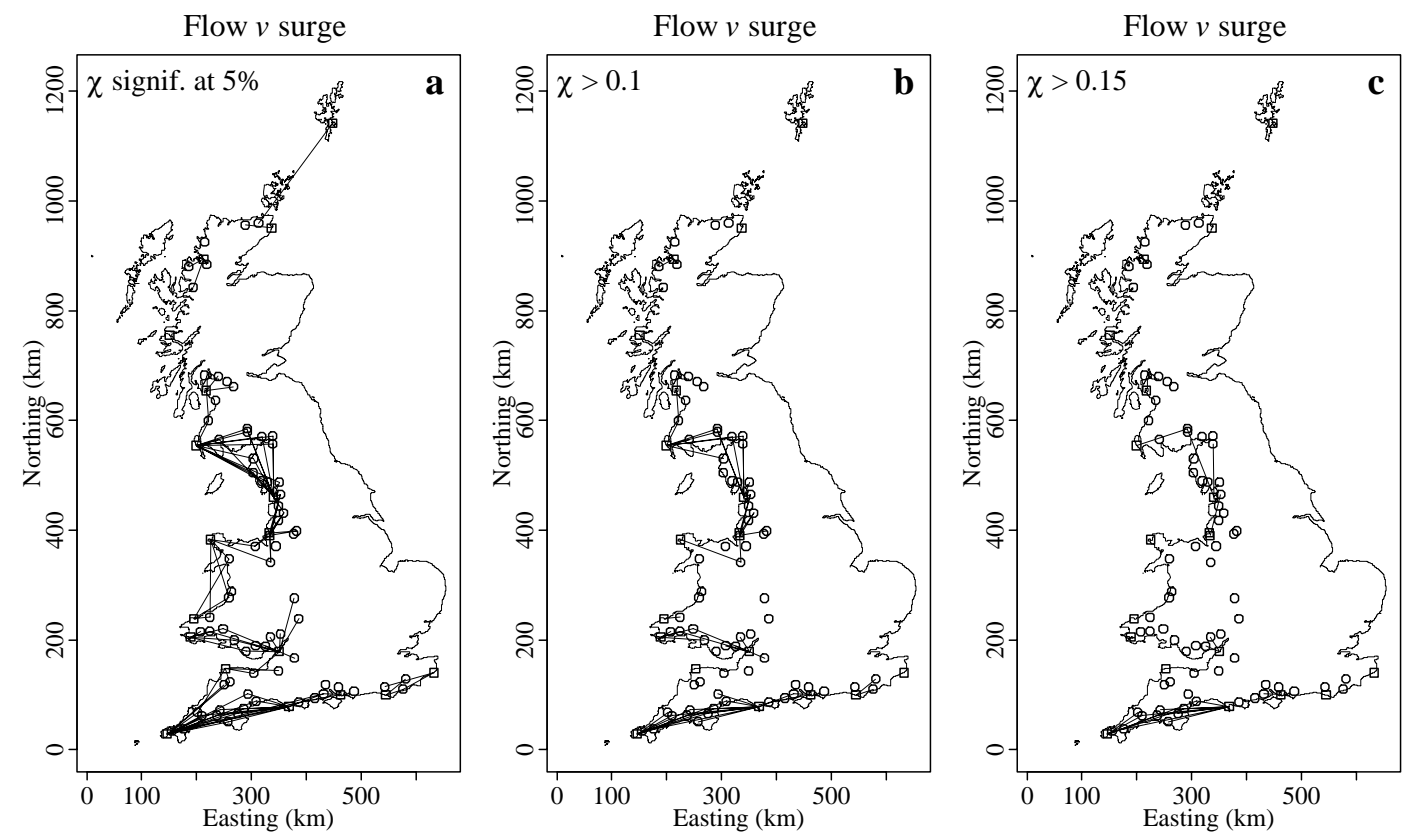

Fig. 3. Dependence between river flow and daily maximum sea surge. Lines connect neighbouring station-pairs with $\chi$ exceeding a) the $95 \%$ point (significant dependence), b) 0.1 , and c) 0.15 . 

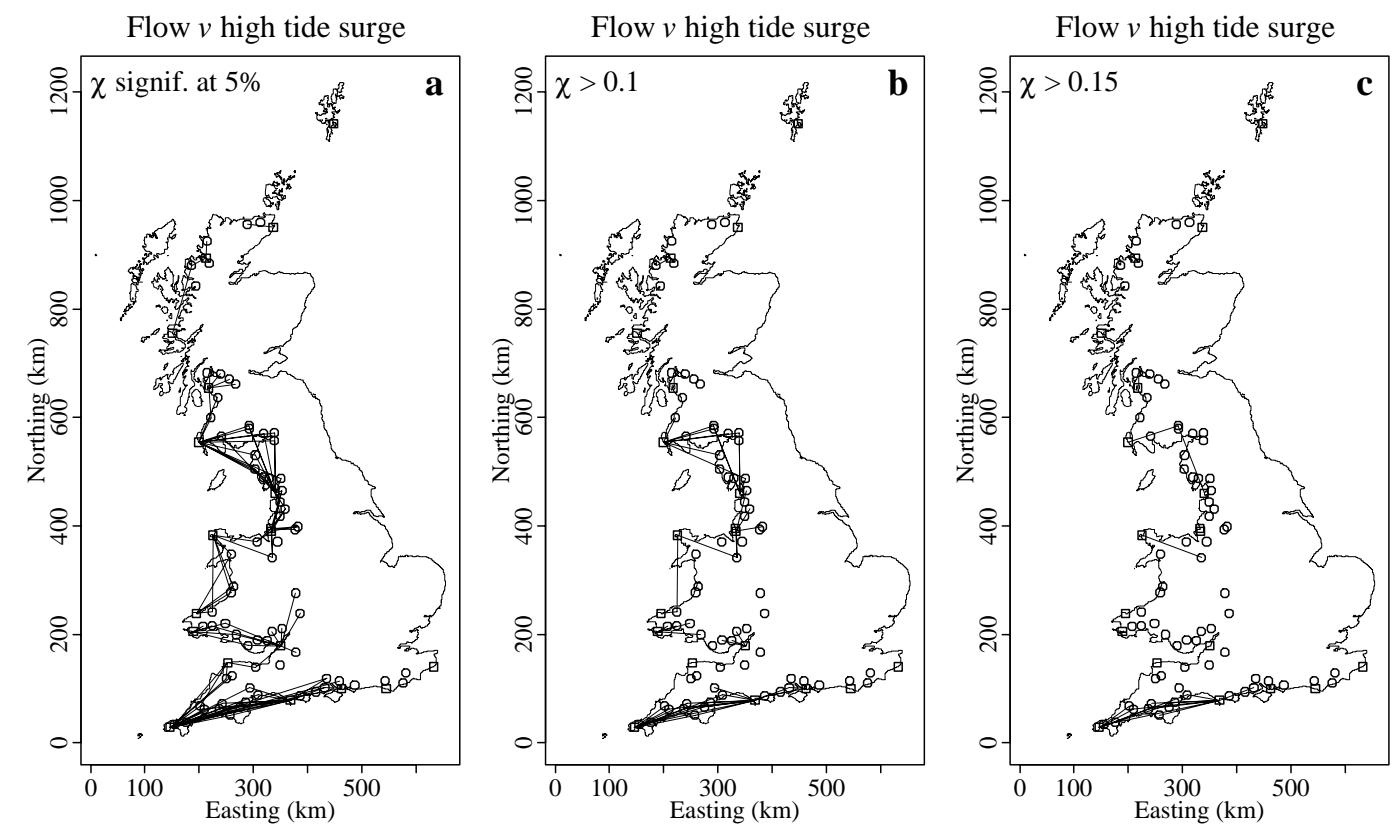

Fig. 4. Dependence between river flow and daily maximum sea surge occurring at high tide. Lines connect neighbouring station-pairs with $\chi$ exceeding a) the $95 \%$ point (significant dependence), b) 0.1 , and c) 0.15 .

south coast of England (Fig. 3, 4) may be related to these being generally permeable, predominantly chalk, catchments which respond slowly to rainfall. Therefore, runoff may not necessarily form on the same day as the surge occurs. The intrusion of externally generated surges from the North Sea into the English Channel may also play a part in weakening the flow-surge dependence. There is some support for weaker dependence on the eastern than on the western part of the south coast in the precipitation-flow and precipitationsurge analyses, respectively (not shown).

Table A1 in the Appendix shows the estimated dependence, $\chi$, and the associated $5 \%$ significance level and limits of the $90 \%$ confidence interval.

The present study finds significant dependence between daily mean river flow at 57005 (Taff at Pontypridd) and surge at Avonmouth. However, using peak flow data for the same station and total water levels at Cardiff (the highest water level nearest in time to the flow peak) Samuels and Burt (2002) did not find significant dependence. The effect of different resolutions may be a contributing factor to the different results, but probably the more important reason is the use of total sea level data rather than surge residuals. The surge is more directly related to the weather causing both river flow (via precipitation) and surge, whereas the variation in total sea level at this location arises mainly from the variation in astronomical tide, which is unrelated to the weather driving extreme events. The different results will also be influenced by the different sea level/surge locations and the different methods for estimating dependence.

\section{FLOW-SURGE DEPENDENCE AT HIGH TIDE}

In shallow water, wave characteristics such as speed and amplitude are influenced by water depth. When the increase in water depth due to tide and surge is not negligible compared to the total water depth, complex non-linear interaction between tide and surge will occur. To reduce the influence of this problem on the dependence analysis, the dependence between river flow and daily maximum surge occurring at high tide was estimated (Fig. 4, Table A2 in Appendix). The general pattern of areas with higher dependence is similar to that using the daily maximum surge.

\section{SEASONAL ANALYSIS}

Depressions tend to follow different paths in different seasons, mainly tracking eastwards or north-eastwards between Scotland and Iceland in winter, and crossing northern Britain in summer (Whittaker and Horn, 1984). Because the storm track is likely to affect flow-surge dependence, a seasonal analysis of dependence was carried out.

Figure 5 shows the difference in flow-surge dependence between winter (October-March) and summer (AprilSeptember) for neighbouring station-pairs. Differences in $\chi$ are generally rather small $(<0.05)$ between the seasons, and flow-surge dependence in winter is similar to that for the whole year. For the majority of the station combinations, the absolute difference in $\chi$ is less than 0.02 between the winter and the whole year. 

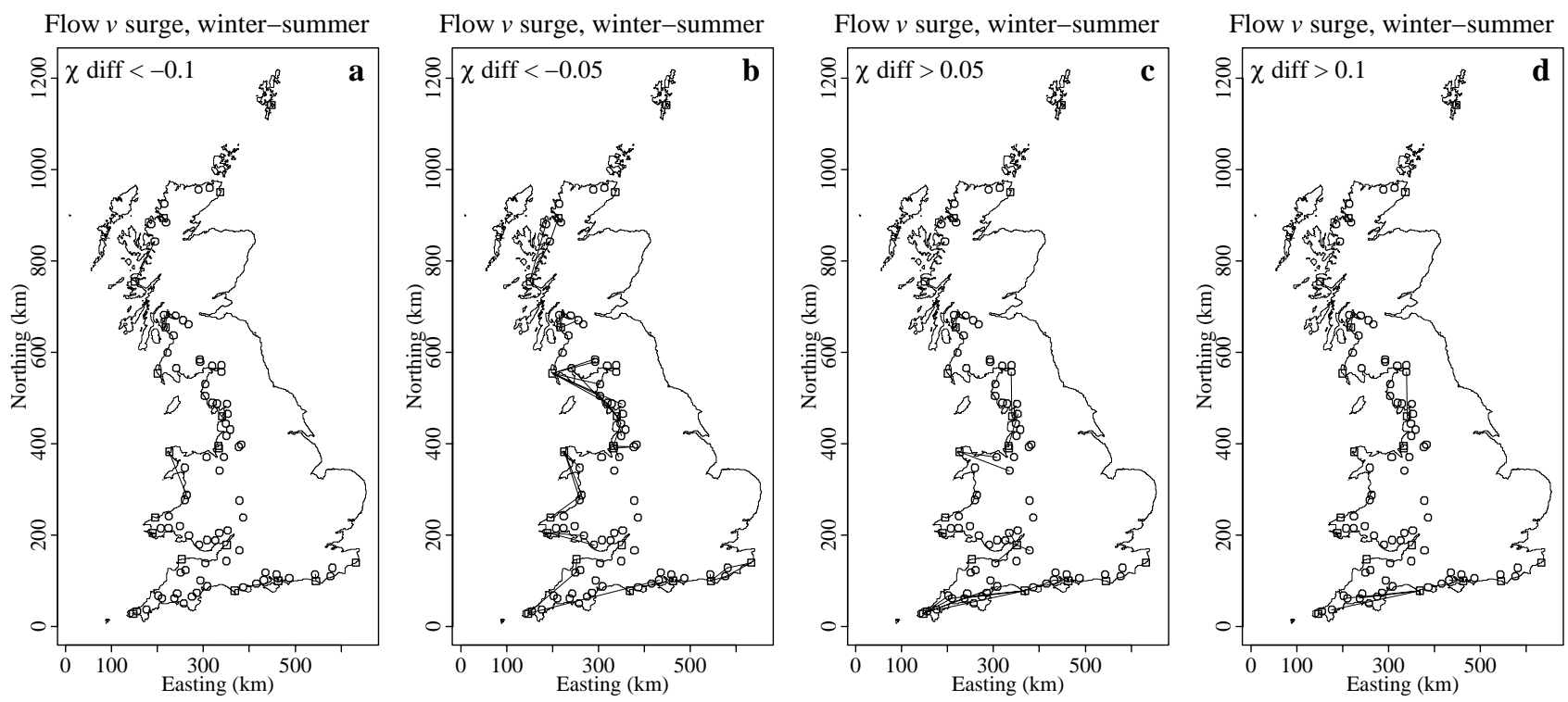

Fig. 5. Seasonal difference in dependence ( $\chi$ for winter minus $\chi$ for summer) between river flow and daily maximum sea surge, for neighbouring stations. Lines connect station-pairs with a difference in $\chi(a)<-0.1,(b)<-0.05,(c)>0.05$ and (d) $>0.1$.

The west coast from Wales and northwards has a slightly stronger flow-surge dependence in summer than in winter. This seems reasonable considering the more southerly storm tracks in summer (compare also with the case studies of storm tracks for high flow and surge events in Figs. 8 to 10). The higher dependence in winter compared to summer on the south coast may be related to higher soil moisture deficits in the south than in the upland areas of Wales and northwards, which would delay or impede runoff into the rivers.
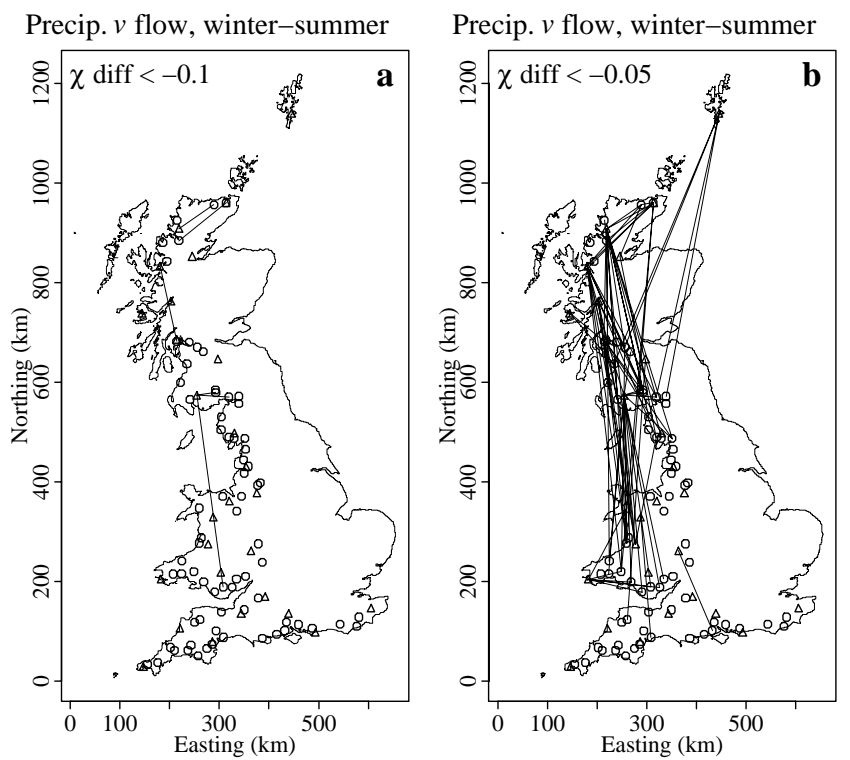

Similar to the flow-surge dependence, dependence between precipitation and river flow is stronger in winter than in summer in the south (Fig. 6). The locations of precipitation gauges are denoted by triangles, and river flow stations by circles. The breakdown in the dependence between precipitation and river flow in the south in summer is consistent with higher soil moisture deficits inhibiting direct runoff. This suggests that the difference in surgeflow dependence between the seasons is indeed an effect of seasonal differences in the rainfall-runoff process.

Fig. 6. Seasonal difference in dependence ( $\chi$ for winter minus $\chi$ for summer) between precipitation and river flow, using all station-pairs. Lines connect station-pairs with a difference in $\chi(a)<-0.1,(b)<-0.05$, (c) $>0.05$ and (d) $>0.1$. 

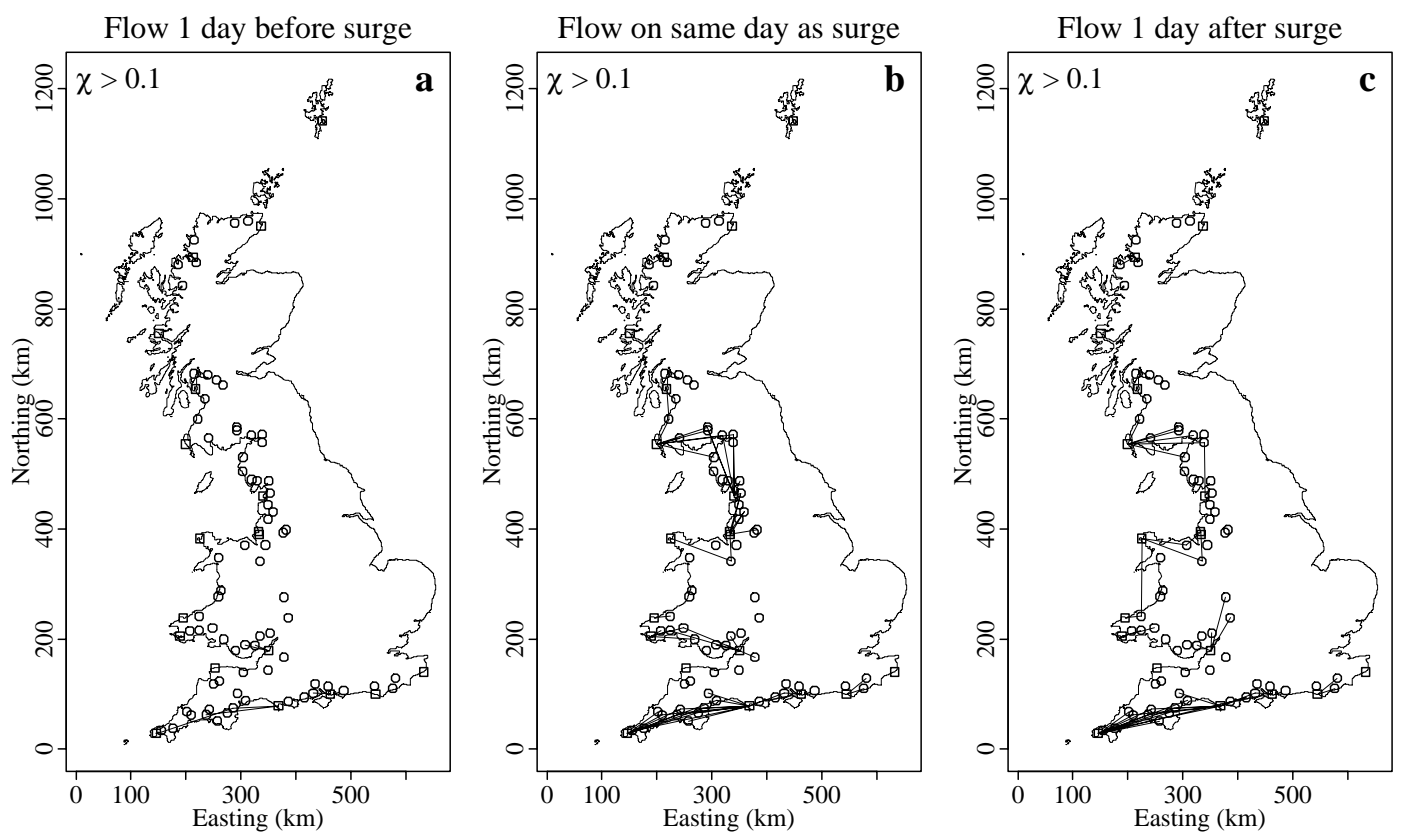

Fig. 7. Dependence between river flow and daily maximum sea surge for different time lags. Lines connect neighbouring station-pairs with $\chi$ exceeding 0.1 .

\section{LAGGED ANALYSIS}

The dependence between river flow and daily maximum sea surge is often strongest when surge and flow occur on the same day (Fig. 7). In general, dependence is strong also for flows lagged one day after the surge. Slowly responding catchments may reach their peak dependence for larger lags. For example, dependence for the large Severn catchments (54001, 54032), reaches its peak when the flow is lagged two days after the surge at Avonmouth.

The dependence between precipitation and daily maximum surge is strongest when they occur on the same day, and not particularly strong for any lag (not shown). There are no station-pairs with $\chi>0.1$ when precipitation is lagged after the surge. The same-day peak in dependence suggests that mainly quickly responding catchments will be at risk from simultaneous occurrence of extreme sea surge and river flow. Dependence between precipitation and river flow is generally strongest when they occur on the same day, and when precipitation precedes the flow by one day (not shown).

\section{INVESTIGATION OF STORM TRACKS}

Reasonably high dependence $(\chi>0.1)$ between river flow and sea surge occurs in three regions on the south and west coasts of Great Britain: the western part of the English south coast, southern Wales, and around the Solway Firth (Fig. 3, 4). Meteorological analyses of a set of extreme surge and/ or flow events were therefore undertaken for these three areas. The regions were treated separately because Lennon (1963) identified different storm tracks associated with extreme surge events at Avonmouth and Liverpool.

Three types of situations were investigated: high surge with moderate or low river flow, both high surge and flow, and high flow and moderate or low surge. Five events of each type, for each region, means that in total 45 events were investigated. Information from Daily Weather Reports (until 1980) and from Daily Weather Summaries (from 1981) was used. From 1998 onwards, the maps only have a resolution of 12 hours, but prior to 1998 the maps are shown every 6 hours.

The daily mean river flow and daily maximum sea surge series were normalised by subtracting the series mean and dividing with the series standard deviation. For each variable separately, these normalised daily series were then averaged in space over all the gauges in each region. Region 1 (western English south coast) comprises 12 flow stations, 44001-49002 (see Appendix A and Fig. 1 for individual station numbers), and surge stations Weymouth and Newlyn. Region 2 (south Wales) comprises 10 flow stations, 5502362001, and surge stations Avonmouth, Milford Haven and Fishguard. Region 3 (Solway Firth area) comprises 15 flow stations, 71001-82001, and surge stations Heysham and Portpatrick.

The normalised flow and surge series were ranked and the nine sets (three regions by three types of events) of five 
events each were selected. The criterion for a small or moderate event was that the normalised flow or surge should be less than zero.

Only five events were analysed in each category, so that the results are therefore only indicative. Contrary to the analysis for the east coast (Svensson and Jones, 2002), where the behaviour within each group was very similar, the west and south coast events are less homogeneous. However, some common features occur within each group, and also between the regions.

\section{Both high sea surge and river flow}

Figures 8 to 10 show the tracks associated with the centre of depressions causing both high surge and river flow in Regions $1-3$. Where possible, the tracks were plotted every 6 hours, during a 48 hour period, marking the 6 -h position with a dot on the line. When only a 12-hourly resolution was available, or when the depression was outside the map (the maps cover different sized areas at different times of day), the intermediate position was estimated through linear interpolation. Towards the beginning or end of the tracks, interpolation was not possible, and the tracks are, therefore, sometimes shorter than 48 hours. Tracks start approximately 36 hours prior to the surge maximum, at Newlyn, Fishguard and Portpatrick respectively, for the three study areas. These surge stations were selected because they had complete records for all the events investigated. The nearest 6 -h location of the depression at surge maximum is encircled on the maps. The storms are denoted on the map with the date (water day, 9.00-9.00 GMT) on which the high sea surge and river flow occurred.

The storm tracks generating both high sea surge and high river flow have a northeasterly direction, and the surge maxima generally occur when the depressions are located over or near the British Isles. The tracks are most homogeneous for Region 2, closely resembling those found by Lennon (1963) to cause high surges at Avonmouth. For Region 1, the northeastward passage of depressions across the Celtic Sea (between Ireland and southwest Britain) in Fig. 8 is consistent with the track in the case study of the 'Morning Cloud' storm surge in the English Channel (George and Thomas, 1978). The storms track progressively to the south with decreasing latitude of the study area. They are generally tracking south of the storms which result in large surges in northeast Britain (Svensson and Jones, 2002), the latter moving northeastwards between Scotland and Iceland.

The minimum central pressure is similar to those of cyclones causing only a high surge, varying between about 950 and $972 \mathrm{hPa}$ for Regions 1 and 2, and between 932 and $967 \mathrm{hPa}$ for Region 3. The low central pressures ensure a

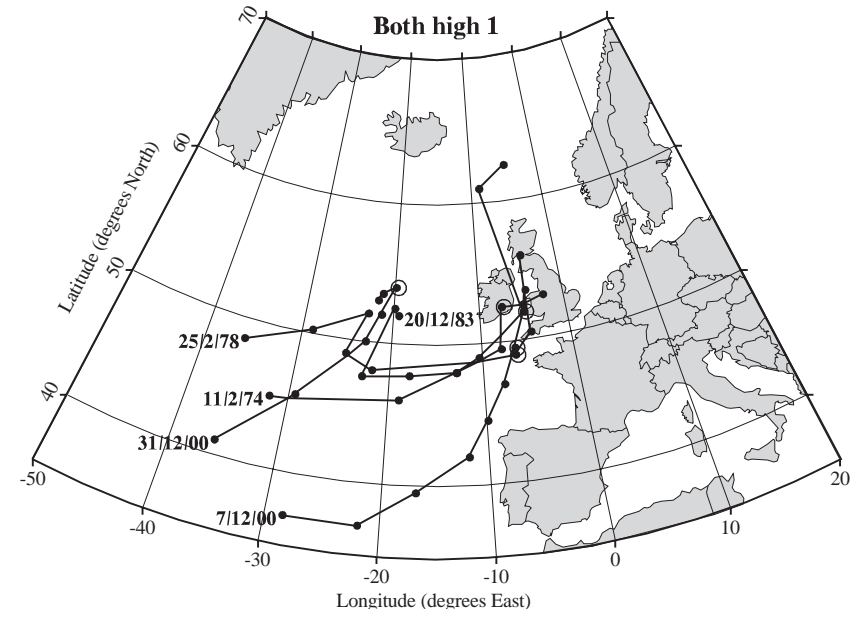

Fig. 8. Tracks of five depressions resulting in both high sea surge and river flow on the western part of the English south coast (Region 1).

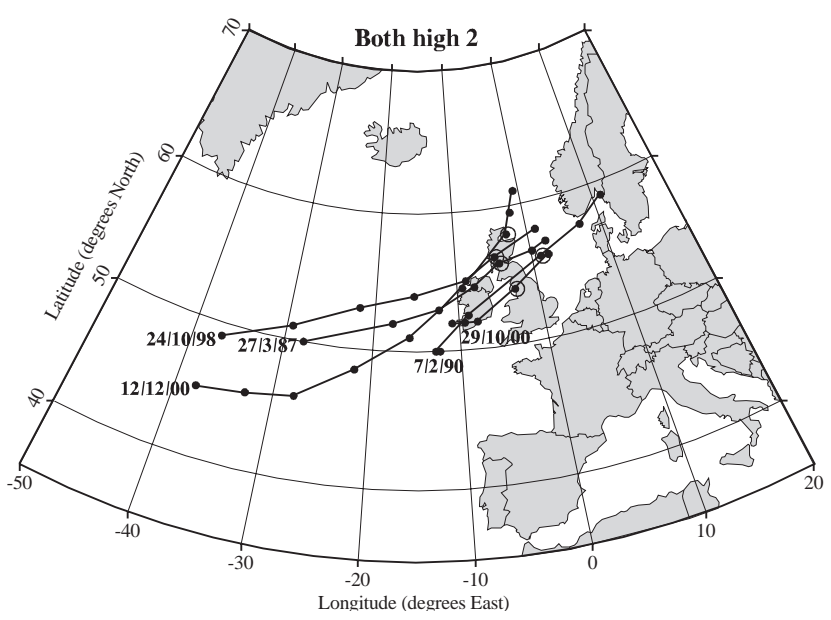

Fig. 9. Tracks of five depressions resulting in both high sea surge and river flow in southern Wales (Region 2).

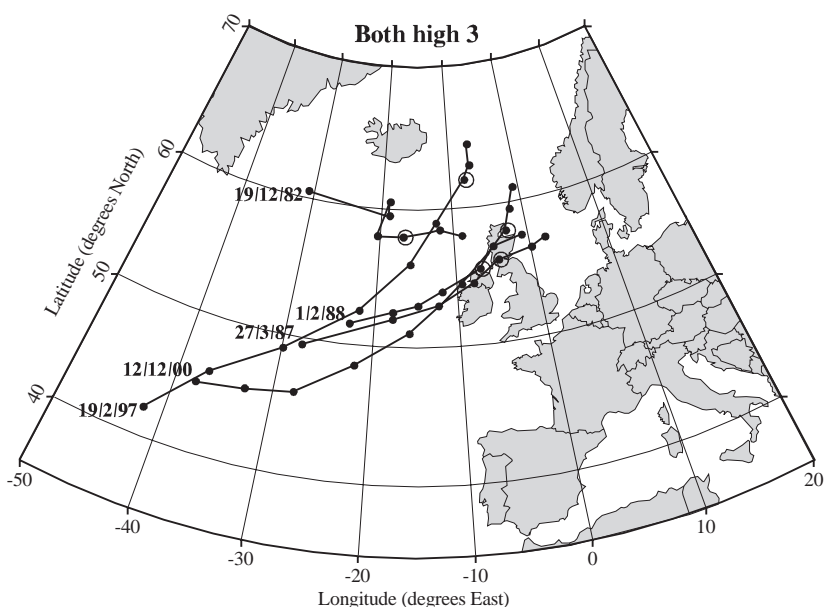

Fig. 10. Tracks of five depressions resulting in both high sea surge and river flow in the Solway area (Region 3). 
lifting of the sea level and the generation of strong winds that drive the water towards the coast. The timing of the minimum pressure is variable, but generally occurs between 4 hours before and 14 hours after the surge maximum. Storms resulting in both high surge and flow tend to move more swiftly than do storms causing only a high surge (not shown), especially in Region 1.

There is generally slight rain or showers in the first 12 to 24 hours, followed by a 12 to 24 -hour period where rainfall may reach moderate or heavy intensity. During the last 12 hours precipitation generally abates, coinciding with the fall in surge magnitude. This suggests that it is mainly reasonably quickly responding catchments that are at risk from river flow and surge peaks occurring simultaneously in the estuaries. The storm seasons are similar for the three regions, starting between October and December, and ending in February or March.

\section{High sea surge and moderate river flow}

Storms resulting in a high sea surge, but a low or moderate river flow, also have low pressures at the centre of the depressions (not shown). However, they follow a more easterly path, and are generally located to the west of Britain at the time of surge maximum. There is often no precipitation in the first 24 hours (because the fronts associated with the cyclone are often located elsewhere), and sometimes not throughout the entire 48-hour period. Especially in the northernmost region (Solway), precipitation sometimes falls as snow or hail, which delays runoff until the precipitation has melted. The storm season is similar for the three regions, starting in September-October and ending in March-May, which is a longer season than for storms resulting in both high surge and flow.

\section{High river flow and moderate sea surge}

The cyclones producing high flow and a low or moderate sea surge were tracked during 48 hours starting at 00.00 GMT on the day before the water day (9.00-9.00 GMT) of extreme river flow. The storm tracks are rather diverse (not shown), sometimes being far away from Great Britain. Some distant storms reach low minimum central pressures (930$974 \mathrm{hPa}$ ) but depressions near Britain have higher minimum central pressures ranging from 984 to $1010 \mathrm{hPa}$. These weak and/or distant depressions are not able to cause a large surge, but rainfall at the associated fronts may be both continuous and, at times, heavy. Towards the north, the start date of the events is earlier and the storm season longer, possibly in response to the shorter season of high soil moisture deficits in the north. The seasons are November-January in Region 1, October-January in Region 2, and September-February in Region 3.

\section{Conclusions}

The measure $\chi$ estimates the dependence between the extremes of variables. This dependence measure was used to estimate the dependence between extreme sea surge, river flow and precipitation, at a daily resolution. For samevariable dependence, surge shows the strongest spatial dependence and precipitation the weakest.

Dependence between river flow and daily maximum sea surge, significant at the $5 \%$ level, may be found at catchments spread along most of the south and west coastline. However, higher dependence $(\chi>0.1)$ is generally found in catchments in hilly areas with a southerly to westerly aspect. Here, precipitation in southwesterly airflow, which is generally the quadrant of prevailing winds, will be orographically enhanced as the first higher ground is encountered. The sloping catchments may respond quickly to the abundant rainfall, and the flow peak may arrive in the estuary on the same day as a large sea surge.

Higher soil moisture deficits in summer, inhibiting direct runoff, may be the reason why flow-surge dependence in the very south is higher in winter than in summer. The upland areas in Wales and northward may be less affected by soil moisture deficits, and more influenced by the effects of the more southerly storm tracks in summer (crossing Great Britain), resulting in higher flow-surge dependence in these areas in summer than in winter. Flow-surge dependence in winter is similar to that for the whole year.

The dependence between river flow and daily maximum sea surge is often strongest when surge and flow occur on the same day. In general, dependence is strong also for flows lagged one day after the surge. The dependence between precipitation and daily maximum surge is strongest when they occur on the same day, and is not particularly strong for any lag.

The storm tracks associated with both high sea surge and high river flow on the west and south coasts have a northeasterly direction, and the surge maxima generally occur when the depressions are located over or near the British Isles. The deep depressions ensure a lifting of the sea level and the generation of strong winds that drive the water towards the coast. Rainfall at the fronts is continuous and sometimes heavy.

Cyclones resulting in only a high sea surge tend to move more slowly and, generally, in an easterly direction. They are often located west of Great Britain as the maximum surge occurs. The storms tend to have similar, low, central pressures to the storms resulting in both high river flow and sea surge but precipitation tends to be slight and is sometimes in frozen form which delays runoff.

Cyclones resulting in only high river flow tend to be 
associated with weak and/or distantly located depressions. They are not able to cause a large surge in the study areas, but rainfall at the fronts may be both continuous and, at times, heavy.

\section{Acknowledgements}

The study was funded by the Department for the Environment, Food and Rural Affairs, project FD2308, within the joint Defra/Environment Agency research theme Risk Evaluation and Understanding of Uncertainty.

The tide and surge data were made available by the Proudman Oceanographic Laboratory under licence for use during this project. The daily precipitation data were made available by the UK Met Office under a licence not specific to this project. Daily mean river flow data were collected by the UK environment agencies and provided by the National River Flow Archive.

\section{References}

Barrow, E. and Hulme, M., 1997. Describing the surface climate of the British Isles. In: Climates of the British Isles - past, present and future, M. Hulme and E. Barrow (Eds.), Routledge, London, UK. 33-62.

Bayliss, A.C. and Jones, R.C., 1993. Peaks-over-threshold flood database: Summary statistics and seasonality. Report No. 121, Institute of Hydrology, Wallingford, UK.

Buishand, T. A., 1984. Bivariate extreme-value data and the stationyear method. J. Hydrol., 69, 77-95.

Coles, J., Heffernan, J. and Tawn, J., 2000. Dependence measures for extreme value analyses. Extremes, 2, 339-365.

Department of Energy, 1977. Guidance on the design and construction of offshore structures: Environmental considerations. Department of Energy design guide.

Department of Energy, 1984. Environmental parameters on the United Kingdom Continental Shelf. Department of Energy Offshore Technology Report OTH 84201.

Efron, B., 1979. Bootstrap methods: another look at the jack-knife. Ann. Statist., 7, 1-26.

Faulkner, D., 1999. Rainfall frequency estimation. Flood Estimation Handbook vol. 2, Institute of Hydrology, Wallingford, UK.

Fisher, N.I., 1993. Some modern statistical techniques for testing and estimation. Chapter 8 in: Statistical analysis of circular data. Cambridge University Press, Cambridge, UK 199-218.

George, K.J. and Thomas, D.K., 1978. The Morning Cloud storm surge in the English Channel. Weather, 33, 227-235.

Good, P., 1994. Permutation tests. Springer, New York, USA.

Harrison, J., 1997. Central and Southern Scotland. In: Regional climates of the British Isles, D. Wheeler and J. Mayes (Eds.), Routledge, London, UK . 205-227.

Heaps, N.S., 1967. Storm surges. Oceanogr. Mar. Biol., An. Rev., $5,11-47$.
Hunt, R.D., 1972. North Sea storm surges. Marine Observer, 42, $115-124$.

Lennon, G.W., 1963. The identification of weather conditions associated with the generation of major storm surges along the west coast of the British Isles, Quart. J. Roy. Meteorol. Soc., 89, 381-394.

Loganathan, G.V., Kuo, C.Y. and Yannaccone, J., 1987. Joint probability distribution of streamsflows and tides in estuaries. Nord. Hydrol., 18, 237-246.

van der Made, J.W., 1969. Design levels in the transition zone between the tidal reach and the river regime reach. In: Hydrology of Deltas, Vol. 2 of Proceedings of the Bucharest Symposium, May 1969. 257-272.

Manley, G., 1970. The climate of the British Isles. In: C. C. Wallén (Ed.), Climates of Northern and Western Europe, Vol. 5 of World Survey of Climatology. Elsevier, Amsterdam, The Netherlands. 81-133.

Mantz, P.A. and Wakeling, H.L., 1979. Forecasting flood levels for joint events of rainfall and tidal surge flooding using extreme value statistics. Proc. Inst. Civil Eng., Part 2, 67, 31-50.

Mayes, J. and Wheeler, D., 1997. The anatomy of regional climates in the British Isles. In: Regional climates of the British Isles, D. Wheeler and J. Mayes (Eds.), Routledge, London, UK. 9-44.

Pugh, D.T., 1987. Tides, surges and mean sea-level. Wiley, Chichester, UK.

Robson, A. and Reed, D.W., 1999. Statistical procedures for flood frequency estimation. Flood Estimation Handbook vol. 3, Institute of Hydrology, Wallingford, UK.

Samuels, P.G. and Burt, N., 2002. A new joint probability appraisal of flood risk, Proc. Inst. Civil Eng. - Water \& Marine Eng., 154, 109-115.

Stedinger, J.R., Vogel, R.M. and Foufoula-Georgiou, E., 1993. Frequency analysis of extreme events. In: Handbook of Hydrology, D. R. Maidment (Ed.), McGraw-Hill, London, UK. 18.1-18.66.

Svensson, C. and Jones, D.A., 2000. Dependence between extreme sea surge, river flow and precipitation: a study in eastern Britain. Report to MAFF, project number FD0206. CEH Wallingford, Wallingford, UK.

Svensson, C. and Jones, D.A., 2002. Dependence between extreme sea surge, river flow and precipitation in eastern Britain. Int. $J$. Climatol., 22, 1149-1168.

Svensson, C. and Jones, D.A., 2003. Dependence between extreme sea surge, river flow and precipitation: a study in south and west Britain. R\&D Interim Technical Report FD2308/TR3 to Defra. CEH Wallingford, Wallingford, UK.

Svensson, C. and Jones, D.A., 2004. Sensitivity to storm track of the dependence between extreme sea surges and river flows around Britain. In: Hydrology: Science and Practice for the $21^{\text {st }}$ Century, Vol. 1, B. Webb, N. Arnell, C. Onof, N. MacIntyre, R. Gurney and C. Kirby (Eds.), British Hydrological Society, 239a-245a.

Wallén, C.C., 1970. Introduction. In: Climates of Northern and Western Europe, Vol. 5 of World Survey of Climatology, C.C. Wallén (Ed.), Elsevier, Amsterdam, The Netherlands. 1-21.

Weston, A.E., 1979. The measurement of interactive freshwater and tidal flows in the river Dee, north Wales. J. Inst. Water Eng. Scientists, 33, 69-79.

Whittaker, L.M. and Horn, L.H., 1984. Northern hemisphere extratropical cyclone activity for four mid-season months. $J$. Climatol., 4, 297-310. 


\section{Appendix}

Table A1. Dependence measure $\chi$, values of $\chi$ corresponding to the $5 \%$ significance level and to the upper and lower limits of the $90 \%$ confidence interval, for dependence between extreme daily mean river flow and daily maximum sea surge.

\begin{tabular}{|c|c|c|c|c|c|c|c|c|c|c|c|}
\hline $\begin{array}{l}\text { Flow } \\
\text { station }\end{array}$ & $\begin{array}{l}\text { Surge } \\
\text { station }\end{array}$ & $\chi$ & $\begin{array}{l}5 \% \\
\text { signif. } \\
\text { level }\end{array}$ & $\begin{array}{l}90 \% \\
\text { conf. } \\
\text { inter- } \\
\text { val, } \\
\text { lower } \\
\text { limit }\end{array}$ & $\begin{array}{l}90 \% \\
\text { conf. } \\
\text { inter- } \\
\text { val, } \\
\text { upper } \\
\text { limit }\end{array}$ & $\begin{array}{l}\text { Flow } \\
\text { station }\end{array}$ & $\begin{array}{l}\text { Surge } \\
\text { station }\end{array}$ & $\chi$ & $\begin{array}{l}5 \% \\
\text { signif. } \\
\text { level }\end{array}$ & $\begin{array}{l}90 \% \\
\text { conf. } \\
\text { inter- } \\
\text { val, } \\
\text { lower } \\
\text { limit }\end{array}$ & $\begin{array}{c}90 \% \\
\text { conf. } \\
\text { inter- } \\
\text { val, } \\
\text { upper } \\
\text { limit }\end{array}$ \\
\hline 40021 & Dover & -0.01 & 0.04 & -0.01 & 0.03 & 49001 & Ilfracombe & 0.06 & 0.04 & 0.01 & 0.13 \\
\hline 40021 & Newhaven & 0.15 & 0.07 & 0.05 & 0.29 & 49002 & Newlyn & 0.09 & 0.05 & 0.06 & 0.15 \\
\hline 41004 & Dover & 0.06 & 0.05 & 0.00 & 0.10 & 49002 & Ilfracombe & 0.03 & 0.05 & -0.01 & 0.08 \\
\hline 41004 & Newhaven & -0.01 & 0.05 & -0.01 & 0.15 & 50001 & Newlyn & 0.07 & 0.05 & 0.04 & 0.11 \\
\hline 41017 & Dover & 0.03 & 0.03 & 0.00 & 0.06 & 50001 & Ilfracombe & 0.05 & 0.03 & 0.01 & 0.12 \\
\hline 41017 & Newhaven & 0.13 & 0.05 & 0.05 & 0.23 & 50002 & Newlyn & 0.06 & 0.05 & 0.01 & 0.10 \\
\hline 41023 & Newhaven & 0.01 & 0.04 & -0.01 & 0.05 & 50002 & Ilfracombe & 0.03 & 0.03 & -0.01 & 0.09 \\
\hline 41023 & Portsmouth & 0.04 & 0.06 & 0.01 & 0.10 & 51003 & Ilfracombe & 0.09 & 0.04 & 0.02 & 0.13 \\
\hline 42003 & Portsmouth & 0.23 & 0.07 & 0.08 & 0.34 & 51003 & Avonmouth & 0.08 & 0.06 & 0.02 & 0.15 \\
\hline 42003 & Weymouth & 0.14 & 0.07 & -0.01 & 0.25 & 52009 & Ilfracombe & 0.04 & 0.03 & -0.01 & 0.08 \\
\hline 42003 & Newlyn & 0.06 & 0.03 & 0.04 & 0.13 & 52009 & Avonmouth & 0.01 & 0.04 & -0.01 & 0.13 \\
\hline 42004 & Portsmouth & 0.06 & 0.07 & -0.01 & 0.15 & 53018 & Avonmouth & 0.11 & 0.03 & 0.04 & 0.18 \\
\hline 42004 & Weymouth & 0.07 & 0.07 & -0.01 & 0.15 & 54001 & Avonmouth & 0.05 & 0.04 & 0.02 & 0.11 \\
\hline 42004 & Newlyn & 0.03 & 0.05 & 0.00 & 0.06 & 54032 & Avonmouth & 0.06 & 0.04 & 0.01 & 0.11 \\
\hline 42006 & Portsmouth & 0.06 & 0.06 & 0.03 & 0.10 & 55023 & Avonmouth & 0.10 & 0.03 & 0.04 & 0.18 \\
\hline 42006 & Newlyn & 0.03 & 0.06 & 0.00 & 0.05 & 56001 & Avonmouth & 0.21 & 0.04 & 0.13 & 0.30 \\
\hline 43021 & Portsmouth & 0.03 & 0.06 & -0.01 & 0.11 & 56002 & Avonmouth & 0.22 & 0.06 & 0.10 & 0.30 \\
\hline 43021 & Weymouth & 0.07 & 0.08 & -0.01 & 0.12 & 57005 & Avonmouth & 0.14 & 0.05 & 0.05 & 0.20 \\
\hline 43021 & Newlyn & 0.01 & 0.07 & -0.01 & 0.05 & 58001 & Avonmouth & 0.05 & 0.04 & -0.01 & 0.11 \\
\hline 44001 & Portsmouth & 0.13 & 0.10 & 0.03 & 0.24 & 58001 & Milford Haven & \multicolumn{2}{|c|}{0.060 .04} & 0.00 & 0.09 \\
\hline 44001 & Weymouth & 0.12 & 0.11 & 0.01 & 0.20 & 59001 & Avonmouth & 0.08 & 0.04 & 0.01 & 0.14 \\
\hline 44001 & Newlyn & 0.07 & 0.07 & 0.02 & 0.13 & 59001 & Milford Haven & 0.13 & 0.03 & 0.06 & 0.18 \\
\hline 45001 & Weymouth & 0.13 & 0.06 & -0.01 & 0.26 & 60003 & Avonmouth & 0.11 & 0.04 & 0.02 & 0.21 \\
\hline 45001 & Newlyn & 0.07 & 0.05 & 0.03 & 0.12 & 60003 & Milford Haven & 0.13 & 0.04 & 0.06 & 0.20 \\
\hline 45005 & Weymouth & 0.24 & 0.05 & 0.07 & 0.38 & 60010 & Avonmouth & 0.13 & 0.04 & 0.05 & 0.20 \\
\hline 45005 & Newlyn & 0.19 & 0.04 & 0.12 & 0.25 & 60010 & Milford Haven & 0.15 & 0.03 & 0.06 & 0.19 \\
\hline 46002 & Weymouth & 0.25 & 0.07 & 0.14 & 0.39 & 61002 & Milford Haven & 0.14 & 0.03 & 0.06 & 0.19 \\
\hline 46002 & Newlyn & 0.23 & 0.05 & 0.17 & 0.28 & 62001 & Fishguard & 0.14 & 0.03 & 0.08 & 0.20 \\
\hline 46003 & Weymouth & 0.16 & 0.06 & -0.01 & 0.30 & 62001 & Holyhead & 0.09 & 0.04 & 0.03 & 0.18 \\
\hline 46003 & Newlyn & 0.14 & 0.05 & 0.09 & 0.19 & 63001 & Fishguard & 0.04 & 0.03 & 0.01 & 0.07 \\
\hline 47001 & Weymouth & 0.20 & 0.05 & 0.07 & 0.32 & 63001 & Holyhead & 0.03 & 0.02 & -0.01 & 0.07 \\
\hline 47001 & Newlyn & 0.11 & 0.04 & 0.05 & 0.17 & 64006 & Fishguard & 0.02 & 0.02 & -0.01 & 0.06 \\
\hline 47004 & Weymouth & 0.24 & 0.06 & 0.08 & 0.42 & 64006 & Holyhead & -0.01 & 0.02 & -0.01 & 0.04 \\
\hline 47004 & Newlyn & 0.16 & 0.05 & 0.09 & 0.22 & 65001 & Fishguard & 0.04 & 0.03 & 0.01 & 0.08 \\
\hline 47007 & Weymouth & 0.18 & 0.06 & 0.05 & 0.35 & 65001 & Holyhead & 0.06 & 0.02 & 0.02 & 0.13 \\
\hline 47007 & Newlyn & 0.08 & 0.04 & 0.05 & 0.14 & 66001 & Holyhead & 0.10 & 0.05 & 0.04 & 0.17 \\
\hline 48007 & Weymouth & 0.20 & 0.08 & 0.07 & 0.28 & 66001 & Liverpool P P & 0.05 & 0.04 & 0.03 & 0.10 \\
\hline 48007 & Newlyn & 0.10 & 0.06 & 0.06 & 0.15 & 66001 & Liverpool G D & 0.07 & 0.06 & 0.02 & 0.14 \\
\hline 48011 & Weymouth & 0.25 & 0.05 & 0.10 & 0.35 & 67015 & Holyhead & 0.13 & 0.05 & 0.05 & 0.22 \\
\hline 48011 & Newlyn & 0.17 & 0.05 & 0.09 & 0.24 & 67015 & Liverpool P P & 0.08 & 0.04 & 0.04 & 0.14 \\
\hline 49001 & Newlyn & 0.16 & 0.04 & 0.09 & 0.23 & 67015 & Liverpool G D & 0.15 & 0.09 & 0.08 & 0.24 \\
\hline
\end{tabular}


Table A1 Continued.

\begin{tabular}{|c|c|c|c|c|c|c|c|c|c|c|c|}
\hline $\begin{array}{l}\text { Flow } \\
\text { station }\end{array}$ & $\begin{array}{l}\text { Surge } \\
\text { station }\end{array}$ & $\chi$ & $\begin{array}{l}5 \% \\
\text { signif. } \\
\text { level }\end{array}$ & $\begin{array}{l}90 \% \\
\text { conf. } \\
\text { inter } \\
\text {-val, } \\
\text { lower } \\
\text { limit }\end{array}$ & $\begin{array}{l}90 \% \\
\text { conf. } \\
\text { inte } \\
\text {-val, } \\
\text { ipper } \\
\text { limit }\end{array}$ & $\begin{array}{l}\text { Flow } \\
\text { station }\end{array}$ & $\begin{array}{l}\text { Surge } \\
\text { station }\end{array}$ & $\chi$ & $\begin{array}{l}5 \% \\
\text { signif. } \\
\text { level }\end{array}$ & $\begin{array}{l}90 \% \\
\text { conf. } \\
\text { inter } \\
\text {-val, } \\
\text { lower } \\
\text { limit }\end{array}$ & $\begin{array}{l}90 \% \\
\text { conf } \\
\text { inte } \\
\text {-val, } \\
\text { upper } \\
\text { limit }\end{array}$ \\
\hline 68020 & Holyhead & -0.01 & 0.04 & -0.01 & 0.03 & 77001 & Portpatrick & 0.13 & 0.03 & 0.08 & 0.20 \\
\hline 68020 & Liverpool G D & -0.01 & 0.08 & -0.01 & 0.06 & 78003 & Heysham & 0.11 & 0.03 & 0.06 & 0.20 \\
\hline 69002 & Liverpool P P & 0.10 & 0.04 & 0.06 & 0.17 & 78003 & Portpatrick & 0.14 & 0.03 & 0.10 & 0.20 \\
\hline 69002 & Liverpool G D & 0.09 & 0.06 & 0.04 & 0.24 & 79002 & Heysham & 0.19 & 0.02 & 0.10 & 0.27 \\
\hline 69007 & Liverpool P P & -0.01 & 0.06 & -0.01 & -0.01 & 79002 & Portpatrick & 0.20 & 0.03 & 0.12 & 0.28 \\
\hline 69007 & Liverpool G D & 0.06 & 0.07 & -0.01 & 0.14 & 79005 & Heysham & 0.14 & 0.03 & 0.10 & 0.23 \\
\hline 70004 & Liverpool P P & 0.06 & 0.04 & -0.01 & 0.16 & 79005 & Portpatrick & 0.15 & 0.03 & 0.08 & 0.22 \\
\hline 70004 & Liverpool G D & 0.04 & 0.07 & -0.01 & 0.22 & 81002 & Heysham & 0.07 & 0.02 & 0.03 & 0.10 \\
\hline 70004 & Heysham & 0.03 & 0.04 & -0.01 & 0.07 & 81002 & Portpatrick & 0.11 & 0.03 & 0.06 & 0.17 \\
\hline 71001 & Liverpool P P & 0.13 & 0.03 & 0.08 & 0.19 & 82001 & Portpatrick & 0.13 & 0.02 & 0.08 & 0.20 \\
\hline 71001 & Liverpool G D & 0.10 & 0.04 & -0.01 & 0.17 & 82001 & Millport & 0.10 & 0.03 & 0.05 & 0.18 \\
\hline 71001 & Heysham & 0.09 & 0.03 & 0.04 & 0.14 & 83005 & Portpatrick & 0.02 & 0.04 & -0.01 & 0.07 \\
\hline 72004 & Liverpool P P & 0.16 & 0.04 & 0.08 & 0.27 & 83005 & Millport & 0.01 & 0.05 & -0.01 & 0.06 \\
\hline 72004 & Liverpool G D & 0.12 & 0.04 & -0.01 & 0.23 & 84001 & Millport & 0.04 & 0.04 & -0.01 & 0.10 \\
\hline 72004 & Heysham & 0.11 & 0.03 & 0.04 & 0.16 & 84013 & Millport & 0.10 & 0.05 & 0.01 & 0.14 \\
\hline 72008 & Liverpool P P & 0.09 & 0.04 & 0.01 & 0.18 & 85001 & Millport & 0.05 & 0.04 & 0.02 & 0.11 \\
\hline 72008 & Liverpool G D & -0.01 & 0.07 & -0.01 & 0.08 & 86001 & Millport & 0.03 & 0.03 & -0.01 & 0.07 \\
\hline 72008 & Heysham & 0.03 & 0.02 & 0.00 & 0.07 & 93001 & Tobermory & 0.02 & 0.07 & -0.01 & 0.06 \\
\hline 73002 & Heysham & 0.05 & 0.03 & 0.03 & 0.10 & 93001 & Ullapool & 0.07 & 0.07 & 0.01 & 0.12 \\
\hline 73002 & Portpatrick & 0.05 & 0.04 & 0.03 & 0.10 & 94001 & Tobermory & 0.05 & 0.09 & -0.01 & 0.11 \\
\hline 73005 & Heysham & 0.11 & 0.03 & 0.05 & 0.21 & 94001 & Ullapool & 0.10 & 0.06 & 0.04 & 0.16 \\
\hline 73005 & Portpatrick & 0.08 & 0.04 & 0.04 & 0.14 & 95001 & Ullapool & 0.05 & 0.06 & 0.00 & 0.14 \\
\hline 74001 & Heysham & 0.09 & 0.02 & 0.03 & 0.13 & 95001 & Wick & 0.04 & 0.05 & -0.01 & 0.09 \\
\hline 74001 & Portpatrick & 0.08 & 0.03 & 0.04 & 0.14 & 95002 & Ullapool & 0.09 & 0.06 & 0.01 & 0.19 \\
\hline 74006 & Heysham & 0.03 & 0.02 & 0.00 & 0.07 & 96001 & Ullapool & 0.02 & 0.04 & -0.01 & 0.07 \\
\hline 74006 & Portpatrick & 0.03 & 0.02 & -0.01 & 0.07 & 96001 & Wick & 0.03 & 0.03 & -0.01 & 0.06 \\
\hline 75002 & Heysham & 0.07 & 0.04 & 0.04 & 0.11 & 96001 & Lerwick & 0.03 & 0.04 & -0.01 & 0.07 \\
\hline 75002 & Portpatrick & 0.13 & 0.03 & 0.06 & 0.15 & 97002 & Ullapool & 0.01 & 0.03 & -0.01 & 0.06 \\
\hline 76007 & Heysham & 0.15 & 0.05 & 0.09 & 0.20 & 97002 & Wick & 0.00 & 0.03 & -0.01 & 0.04 \\
\hline 76007 & Portpatrick & 0.09 & 0.04 & 0.05 & 0.14 & 97002 & Lerwick & 0.05 & 0.04 & -0.01 & 0.09 \\
\hline 77001 & Heysham & 0.12 & 0.04 & 0.06 & 0.18 & & & & & & \\
\hline
\end{tabular}


Table A2 Dependence measure $\chi$, values of $\chi$ corresponding to the $5 \%$ significance level and to the upper and lower limits of the $90 \%$ confidence interval, for dependence between extreme daily mean river flow and daily maximum sea surge occurring at high tide.

\begin{tabular}{|c|c|c|c|c|c|c|c|c|c|c|c|}
\hline $\begin{array}{l}\text { Flow } \\
\text { station }\end{array}$ & $\begin{array}{l}\text { Surge } \\
\text { station }\end{array}$ & $\chi$ & $\begin{array}{l}5 \% \\
\text { signif. } \\
\text { level }\end{array}$ & $\begin{array}{l}90 \% \\
\text { conf. } \\
\text { inter- } \\
\text { val, } \\
\text { lower } \\
\text { limit }\end{array}$ & $\begin{array}{l}90 \% \\
\text { conf. } \\
\text { inter- } \\
\text { val, } \\
\text { upper } \\
\text { limit }\end{array}$ & $\begin{array}{l}\text { Flow } \\
\text { station }\end{array}$ & $\begin{array}{l}\text { Surge } \\
\text { station }\end{array}$ & $\chi$ & $\begin{array}{l}5 \% \\
\text { signif. } \\
\text { level }\end{array}$ & $\begin{array}{l}90 \% \\
\text { conf. } \\
\text { inter- } \\
\text { val, } \\
\text { lower } \\
\text { limit }\end{array}$ & $\begin{array}{l}90 \% \\
\text { conf. } \\
\text { inter- } \\
\text { val, } \\
\text { upper } \\
\text { limit }\end{array}$ \\
\hline 40021 & Dover & -0.01 & 0.04 & -0.01 & 0.04 & 49001 & Ilfracombe & 0.08 & 0.03 & 0.03 & 0.15 \\
\hline 40021 & Newhaven & 0.02 & 0.08 & -0.01 & 0.11 & 49002 & Newlyn & 0.11 & 0.05 & 0.07 & 0.17 \\
\hline 41004 & Dover & 0.01 & 0.04 & -0.01 & 0.05 & 49002 & Ilfracombe & 0.08 & 0.04 & 0.04 & 0.1 \\
\hline 41004 & Newhaven & 0.04 & 0.05 & -0.01 & 0.12 & 50001 & Newlyn & 0.07 & 0.04 & 0.04 & 0.12 \\
\hline 41017 & Dover & 0.01 & 0.04 & -0.01 & 0.05 & 50001 & Ilfracombe & 0.03 & 0.03 & -0.01 & 0.12 \\
\hline 41017 & Newhaven & 0.04 & 0.05 & -0.01 & 0.07 & 50002 & Newlyn & 0.07 & 0.04 & 0.03 & 0.11 \\
\hline 41023 & Newhaven & 0.02 & 0.06 & -0.01 & 0.05 & 50002 & Ilfracombe & 0.05 & 0.04 & 0.01 & 0.16 \\
\hline 41023 & Portsmouth & 0.04 & 0.07 & 0.00 & 0.08 & 51003 & Ilfracombe & 0.05 & 0.04 & 0.01 & 0.15 \\
\hline 42003 & Portsmouth & 0.11 & 0.07 & 0.05 & 0.27 & 51003 & Avonmouth & 0.08 & 0.04 & 0.02 & 0.11 \\
\hline 42003 & Weymouth & 0.17 & 0.06 & 0.06 & 0.34 & 52009 & Ilfracombe & 0.02 & 0.02 & -0.01 & 0.08 \\
\hline 42003 & Newlyn & 0.06 & 0.04 & 0.02 & 0.15 & 52009 & Avonmouth & 0.02 & 0.04 & -0.01 & 0.09 \\
\hline 42004 & Portsmouth & 0.04 & 0.08 & -0.01 & 0.18 & 53018 & Avonmouth & 0.10 & 0.03 & 0.01 & 0.12 \\
\hline 42004 & Weymouth & 0.06 & 0.03 & -0.01 & 0.13 & 54001 & Avonmouth & 0.08 & 0.04 & 0.02 & 0.11 \\
\hline 42004 & Newlyn & 0.05 & 0.04 & 0.02 & 0.07 & 54032 & Avonmouth & 0.06 & 0.05 & 0.01 & 0.10 \\
\hline 42006 & Portsmouth & 0.06 & 0.07 & 0.00 & 0.13 & 55023 & Avonmouth & 0.06 & 0.04 & 0.01 & 0.10 \\
\hline 42006 & Newlyn & 0.05 & 0.05 & 0.03 & 0.07 & 56001 & Avonmouth & 0.14 & 0.04 & 0.05 & 0.23 \\
\hline 43021 & Portsmouth & 0.06 & 0.08 & 0.00 & 0.14 & 56002 & Avonmouth & 0.13 & 0.08 & 0.04 & 0.20 \\
\hline 43021 & Weymouth & 0.04 & 0.06 & 0.00 & 0.08 & 57005 & Avonmouth & 0.10 & 0.05 & 0.04 & 0.24 \\
\hline 43021 & Newlyn & 0.05 & 0.06 & 0.02 & 0.08 & 58001 & Avonmouth & 0.05 & 0.04 & -0.01 & 0.13 \\
\hline 44001 & Portsmouth & 0.11 & 0.10 & 0.01 & 0.27 & 58001 & Milford Haven & 0.06 & 0.03 & 0.00 & 0.09 \\
\hline 44001 & Weymouth & 0.13 & 0.07 & 0.01 & 0.24 & 59001 & Avonmouth & 0.08 & 0.04 & 0.02 & 0.21 \\
\hline 44001 & Newlyn & 0.09 & 0.06 & 0.04 & 0.15 & 59001 & Milford Haven & 0.13 & 0.03 & 0.06 & 0.17 \\
\hline 45001 & Weymouth & 0.12 & 0.06 & 0.02 & 0.21 & 60003 & Avonmouth & 0.07 & 0.06 & 0.01 & 0.14 \\
\hline 45001 & Newlyn & 0.08 & 0.05 & 0.03 & 0.14 & 60003 & Milford Haven & 0.12 & 0.04 & 0.02 & 0.22 \\
\hline 45005 & Weymouth & 0.22 & 0.05 & 0.03 & 0.35 & 60010 & Avonmouth & 0.09 & 0.06 & 0.01 & 0.16 \\
\hline 45005 & Newlyn & 0.18 & 0.03 & 0.11 & 0.24 & 60010 & Milford Haven & 0.14 & 0.03 & 0.06 & 0.18 \\
\hline 46002 & Weymouth & 0.18 & 0.07 & 0.07 & 0.31 & 61002 & Milford Haven & 0.12 & 0.04 & 0.05 & 0.18 \\
\hline 46002 & Newlyn & 0.20 & 0.05 & 0.13 & 0.25 & 62001 & Fishguard & 0.13 & 0.04 & 0.07 & 0.19 \\
\hline 46003 & Weymouth & 0.10 & 0.07 & -0.01 & 0.21 & 62001 & Holyhead & 0.14 & 0.04 & 0.07 & 0.19 \\
\hline 46003 & Newlyn & 0.12 & 0.05 & 0.08 & 0.19 & 63001 & Fishguard & 0.04 & 0.03 & 0.01 & 0.09 \\
\hline 47001 & Weymouth & 0.18 & 0.05 & 0.05 & 0.28 & 63001 & Holyhead & 0.03 & 0.02 & -0.01 & 0.06 \\
\hline 47001 & Newlyn & 0.14 & 0.04 & 0.07 & 0.21 & 64006 & Fishguard & 0.03 & 0.02 & 0.00 & 0.08 \\
\hline 47004 & Weymouth & 0.25 & 0.09 & 0.10 & 0.39 & 64006 & Holyhead & 0.02 & 0.01 & -0.01 & 0.06 \\
\hline 47004 & Newlyn & 0.17 & 0.05 & 0.09 & 0.23 & 65001 & Fishguard & 0.06 & 0.03 & 0.03 & 0.11 \\
\hline 47007 & Weymouth & 0.17 & 0.09 & 0.03 & 0.40 & 65001 & Holyhead & 0.09 & 0.04 & 0.04 & 0.14 \\
\hline 47007 & Newlyn & 0.13 & 0.05 & 0.08 & 0.20 & 66001 & Holyhead & 0.08 & 0.03 & 0.01 & 0.16 \\
\hline 48007 & Weymouth & 0.19 & 0.09 & 0.09 & 0.30 & 66001 & Liverpool P P & 0.04 & 0.04 & 0.01 & 0.09 \\
\hline 48007 & Newlyn & 0.13 & 0.05 & 0.08 & 0.18 & 66001 & Liverpool G D & 0.09 & 0.06 & -0.01 & 0.17 \\
\hline 48011 & Weymouth & 0.26 & 0.06 & 0.11 & 0.38 & 67015 & Holyhead & 0.16 & 0.04 & 0.08 & 0.24 \\
\hline 48011 & Newlyn & 0.16 & 0.05 & 0.08 & 0.23 & 67015 & Liverpool P P & 0.11 & 0.04 & 0.05 & 0.20 \\
\hline 49001 & Newlyn & 0.16 & 0.03 & 0.10 & 0.23 & 67015 & Liverpool G D & 0.15 & 0.09 & 0.03 & 0.26 \\
\hline
\end{tabular}


Table A2 Continued.

\begin{tabular}{|c|c|c|c|c|c|c|c|c|c|c|c|}
\hline $\begin{array}{l}\text { Flow } \\
\text { station }\end{array}$ & $\begin{array}{l}\text { Surge } \\
\text { station }\end{array}$ & $\chi$ & $\begin{array}{l}5 \% \\
\text { signif. } \\
\text { level }\end{array}$ & $\begin{array}{l}90 \% \\
\text { conf. } \\
\text { inter- } \\
\text { val, } \\
\text { lower } \\
\text { limit }\end{array}$ & $\begin{array}{l}90 \% \\
\text { conf. } \\
\text { inter- } \\
\text { val, } \\
\text { upper } \\
\text { limit }\end{array}$ & $\begin{array}{l}\text { Flow } \\
\text { station }\end{array}$ & $\begin{array}{l}\text { Surge } \\
\text { station }\end{array}$ & $\chi$ & $\begin{array}{l}5 \% \\
\text { signif. } \\
\text { level }\end{array}$ & $\begin{array}{l}90 \% \\
\text { conf. } \\
\text { inter- } \\
\text { val, } \\
\text { lower } \\
\text { limit }\end{array}$ & $\begin{array}{l}90 \% \\
\text { conf. } \\
\text { inter- } \\
\text { val, } \\
\text { upper } \\
\text { limit }\end{array}$ \\
\hline 68020 & Holyhead & -0.01 & 0.03 & -0.01 & 0.03 & 77001 & Portpatrick & 0.11 & 0.04 & 0.07 & 0.21 \\
\hline 68020 & Liverpool G D & -0.01 & 0.05 & -0.01 & -0.01 & 78003 & Heysham & 0.10 & 0.03 & 0.05 & 0.16 \\
\hline 69002 & Liverpool P P & 0.11 & 0.04 & 0.03 & 0.15 & 78003 & Portpatrick & 0.13 & 0.03 & 0.08 & 0.19 \\
\hline 69002 & Liverpool G D & 0.09 & 0.07 & -0.01 & 0.23 & 79002 & Heysham & 0.17 & 0.02 & 0.11 & 0.21 \\
\hline 69007 & Liverpool P P & 0.03 & 0.04 & -0.01 & 0.08 & 79002 & Portpatrick & 0.19 & 0.03 & 0.10 & 0.25 \\
\hline 69007 & Liverpool G D & 0.10 & 0.04 & -0.01 & 0.19 & 79005 & Heysham & 0.11 & 0.02 & 0.06 & 0.19 \\
\hline 70004 & Liverpool P P & 0.03 & 0.06 & -0.01 & 0.20 & 79005 & Portpatrick & 0.14 & 0.03 & 0.09 & 0.21 \\
\hline 70004 & Liverpool G D & 0.04 & 0.04 & -0.01 & 0.19 & 81002 & Heysham & 0.05 & 0.03 & 0.02 & 0.10 \\
\hline 70004 & Heysham & 0.04 & 0.03 & 0.01 & 0.08 & 81002 & Portpatrick & 0.10 & 0.03 & 0.03 & 0.13 \\
\hline 71001 & Liverpool P P & 0.11 & 0.03 & 0.05 & 0.19 & 82001 & Portpatrick & 0.12 & 0.03 & 0.06 & 0.18 \\
\hline 71001 & Liverpool G D & 0.07 & 0.04 & -0.01 & 0.20 & 82001 & Millport & 0.09 & 0.03 & 0.01 & 0.15 \\
\hline 71001 & Heysham & 0.07 & 0.03 & 0.03 & 0.13 & 83005 & Portpatrick & 0.05 & 0.03 & 0.01 & 0.09 \\
\hline 72004 & Liverpool P P & 0.13 & 0.03 & 0.03 & 0.21 & 83005 & Millport & 0.01 & 0.03 & -0.01 & 0.06 \\
\hline 72004 & Liverpool G D & 0.07 & 0.04 & -0.01 & 0.21 & 84001 & Millport & 0.06 & 0.05 & 0.01 & 0.10 \\
\hline 72004 & Heysham & 0.08 & 0.04 & 0.03 & 0.16 & 84013 & Millport & 0.07 & 0.03 & 0.01 & 0.11 \\
\hline 72008 & Liverpool P P & 0.09 & 0.02 & 0.02 & 0.17 & 85001 & Millport & 0.06 & 0.04 & 0.03 & 0.11 \\
\hline 72008 & Liverpool G D & -0.01 & 0.05 & -0.01 & 0.05 & 86001 & Millport & 0.03 & 0.03 & -0.01 & 0.10 \\
\hline 72008 & Heysham & 0.05 & 0.03 & 0.03 & 0.11 & 93001 & Tobermory & 0.05 & 0.07 & -0.01 & 0.09 \\
\hline 73002 & Heysham & 0.07 & 0.03 & 0.04 & 0.10 & 93001 & Ullapool & 0.04 & 0.05 & -0.01 & 0.09 \\
\hline 73002 & Portpatrick & 0.05 & 0.04 & 0.03 & 0.10 & 94001 & Tobermory & 0.09 & 0.09 & 0.01 & 0.18 \\
\hline 73005 & Heysham & 0.10 & 0.04 & 0.05 & 0.20 & 94001 & Ullapool & 0.12 & 0.04 & 0.04 & 0.19 \\
\hline 73005 & Portpatrick & 0.11 & 0.05 & 0.07 & 0.17 & 95001 & Ullapool & 0.05 & 0.05 & -0.01 & 0.12 \\
\hline 74001 & Heysham & 0.09 & 0.02 & 0.04 & 0.14 & 95001 & Wick $\quad 0.04$ & 0.04 & 0.00 & 0.08 & \\
\hline 74001 & Portpatrick & 0.09 & 0.03 & 0.04 & 0.14 & 95002 & Ullapool & 0.07 & 0.07 & 0.02 & 0.15 \\
\hline 74006 & Heysham & 0.04 & 0.02 & 0.00 & 0.08 & 96001 & Ullapool & 0.03 & 0.03 & -0.01 & 0.06 \\
\hline 74006 & Portpatrick & 0.05 & 0.02 & 0.01 & 0.10 & 96001 & Wick $\quad 0.05$ & 0.03 & -0.01 & 0.10 & \\
\hline 75002 & Heysham & 0.08 & 0.04 & 0.03 & 0.11 & 96001 & Lerwick & 0.02 & 0.04 & -0.01 & 0.07 \\
\hline 75002 & Portpatrick & 0.12 & 0.03 & 0.06 & 0.15 & 97002 & Ullapool & 0.01 & 0.03 & -0.01 & 0.05 \\
\hline 76007 & Heysham & 0.14 & 0.04 & 0.06 & 0.21 & 97002 & Wick $\quad 0.03$ & 0.04 & -0.01 & 0.07 & \\
\hline 76007 & Portpatrick & 0.08 & 0.04 & 0.05 & 0.13 & 97002 & Lerwick & 0.03 & 0.04 & -0.01 & 0.07 \\
\hline 77001 & Heysham & 0.11 & 0.03 & 0.06 & 0.17 & & & & & & \\
\hline
\end{tabular}

